\title{
Jamaica: Financial System Stability Assessment, including Reports on the Observance of Standards and Codes on the following topics: Basel Core Principles for Effective Banking Supervision, the CPSS Core Principles for Systemically Important Payment Systems, and IMF Monetary and Financial Policy Transparency Codes
}

This Financial System Stability Assessment on Jamaica was prepared by a staff team of the International Monetary Fund and the World Bank as background documentation for the periodic consultation with the member country. It is based on the information available at the time it was completed on March 8, 2006. The views expressed in this document are those of the staff team and do not necessarily reflect the views of the government of Jamaica or the Executive Board of the IMF.

The policy of publication of staff reports and other documents by the IMF allows for the deletion of market-sensitive information.

To assist the IMF in evaluating the publication policy, reader comments are invited and may be sent by e-mail to publicationpolicy@imf.org.

Copies of this report are available to the public from

International Monetary Fund $\bullet$ Publication Services

700 19th Street, N.W. • Washington, D.C. 20431

Telephone: (202) $6237430 \bullet$ Telefax: (202) 6237201

E-mail: publications@imf.org • Internet: http://www.imf.org

Price: $\$ 15.00$ a copy

\section{International Monetary Fund}

Washington, D.C. 



\title{
INTERNATIONAL MONETARY FUND
}

\section{JAMAICA}

\section{Financial System Stability Assessment}

Prepared by the Monetary and Financial Systems and Western Hemisphere Departments

\author{
Approved by Ulrich Baumgartner and Charles Collyns
}

March 8, 2006

This report is based on the work of joint IMF-World Bank missions to Jamaica, May 9-20 and July 6-15, 2005 under the Fund-Bank Financial Sector Assessment Program (FSAP). The missions comprised Messrs. Corker (head, IMF) and Almansi (deputy head, World Bank); Messrs. Sacerdoti and Kwon and Mmes Mitchell-Casselle, Lukonga, and Fernandez (IMF); Messrs. Liu, De Luna Martinez, Bae, Cirasino, Rouillon (World Bank); and Messrs. Hafeman and Cooper (external experts). The missions met with Finance Minister Davies, the Financial Secretary, Bank of Jamaica Governor Latibeaudiere and his staff, the head and staff of the Financial Services Commission and Deposit Insurance Fund, other key officials, and private sector representatives.

The main conclusions are:

- Although the financial system currently appears well-capitalized and supervision has been considerably strengthened in recent years, financial institutions operate in a risky macroeconomic environment. Reducing the large public debt is essential to provide a broad underpinning for financial stability.

- To further lessen vulnerabilities, the priorities are to further strengthen the prudential framework for security dealers, enhance the oversight of conglomerates (which dominate the system), and develop and test crisis management systems.

- Structural priorities are to improve the insolvency and creditor rights regime, overhaul the payments system, and introduce a central securities depository for fixed-income securities.

FSAPs are designed to assess the stability of the financial system as a whole and not that of individual institutions. They have been developed to help countries identify and remedy weaknesses in their financial sector structure, thereby enhancing their resilience to macroeconomic shocks and cross-border contagion. FSAPs do not cover risks that are specific to individual institutions such as asset quality, operational or legal risks, or fraud. 
Contents Page

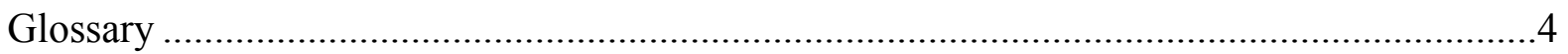

I. Key Points and Macro-Relevant Recommendations .....................................................6

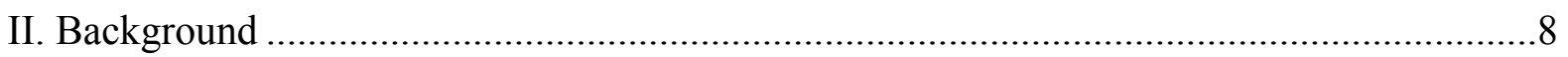

Financial sector structure and developments ....................................... 8

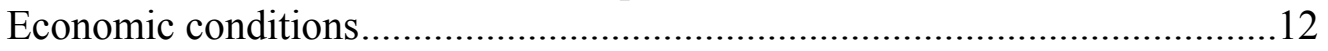

III. Sectoral Assessments .......................................................................................... 18

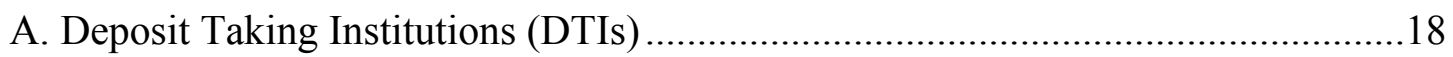

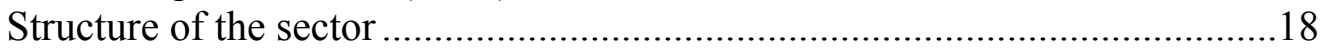

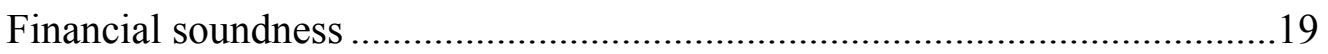

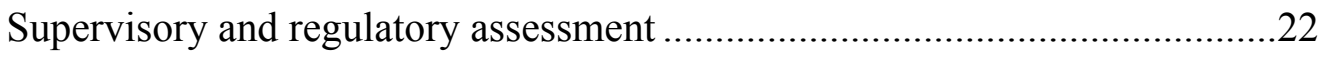

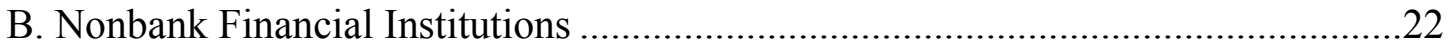

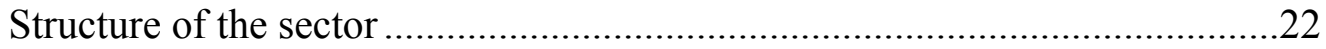

Financial soundness ........................................................................22

Supervisory and regulatory assessment ..................................................26

Encouraging the development of private pensions ....................................22

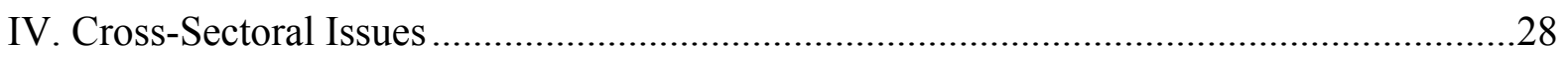

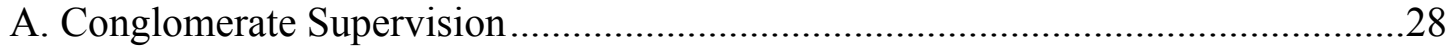

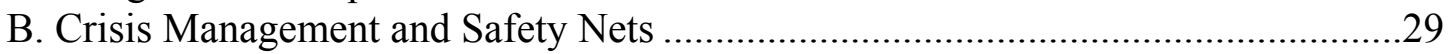

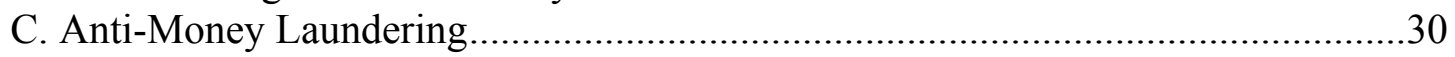

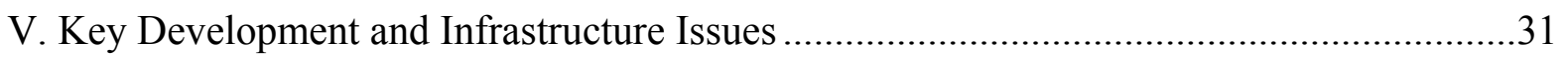

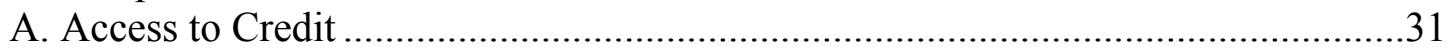

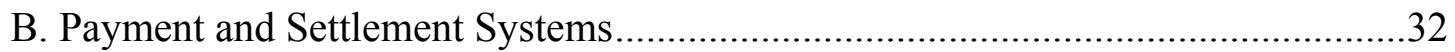

C. Monetary Policy Implementation and Related Market Infrastructure .....................32

D. Ensuring Continued Effective Public Debt Management ......................................33

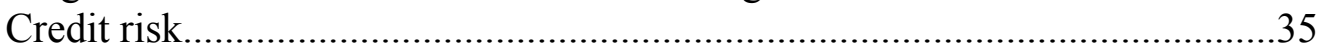

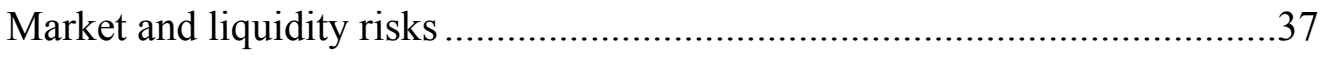

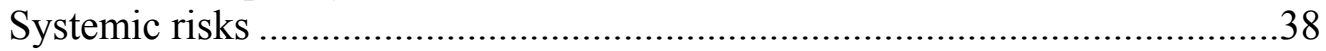

Tables

1. Financial System Structure, 1995-2004 .................................................................... 10

2. Market Share of the Main Financial Conglomerates ................................................... 11

3. Jamaica: Selected Economic Indicators ............................................................................

4. Comparison of Interest Rate Spreads, 2000-05 ........................................................18

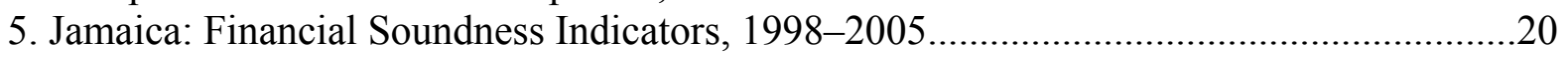

6. Insurance Indicators of Profitability and Soundness, 2001-04 .......................................24

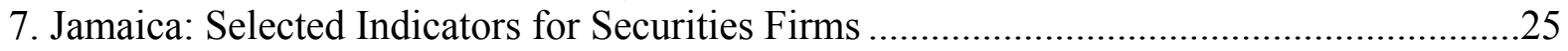

8. Summary of Stress Testing Results, as of End-December 2004 .....................................39

9. Recommended Action Plan to Improve Compliance of the Basel Core Principles.............44 
10. Recommended Actions to Improve Observance of CPSS Core Principles and Central Bank Responsibilities in Applying the CPs.

11. Recommended Action Plan to Improve Observance of IMF's MFP Transparency Code

Practices-Monetary Policy

12. Recommended Action Plan to Improve Observance of IMF's MFP Transparency Code

Practices—Banking Supervision .................................................................................

13. Recommended Action Plan to Improve Observance of IMF's MFP Transparency Code

Practices-JDIC

Figures

1. Assets by Financial Institution, 2004. 13

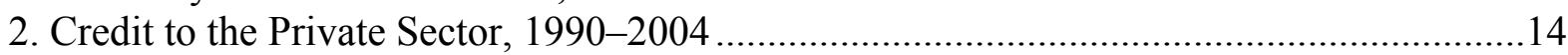

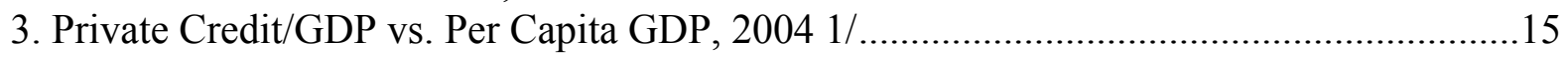

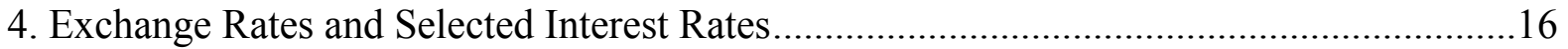

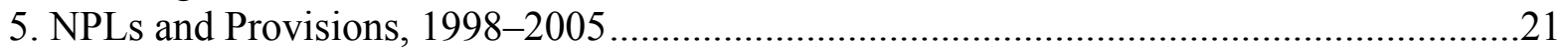

6. Banking Sector: Impact on CAR of an Increase in NPLs................................................36

7. Direct and Indirect Effects of FX Movements: Foreign Currency-Denominated Loans......40

Boxes

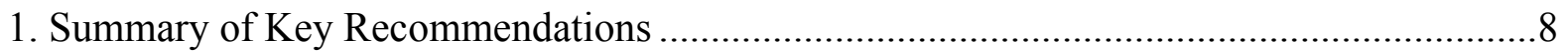

Appendices

Stress Testing of the Banking System

Annexes

Observance of Financial Sector Standards and Codes-Summary Assessments. 


\section{GLOSSARY}

$\mathrm{ACH}$

AML

BA

BCP

BoJ

BoJA

BSA

CBAS

CIFTS

CPSIPS

CPSS

CSD

DIA

DTI

DvP

EFT

FATF

FIA

FISD

FIU

FRC

FSC

FUM

GDDS

GoJ

IADI

IAS

IFRS

IOSCO

JCBA

JCSD automated clearing house

Anti-Money Laundering

Banking Act

Basel Core Principles

Bank of Jamaica

Bank of Jamaica Act

Building Societies Act

Central Bank Accounting System

Customer Inquiry and Funds Transfer System

Core Principles for Systemically Important Payment Systems

Committee for Payment and Settlement Systems

Central Securities Depository

Deposit Insurance Act

Deposit Taking Institutions

delivery versus payment

Electronic Fund Transfer

Financial Action Task Force

Financial Institutions Act

Financial Institutions Supervisory Division

Financial Intelligence Unit

Financial Regulatory Council

Financial Services Commission

funds under management

General Data Dissemination Systems

Government of Jamaica

International Association of Deposit Insurers

international accounting standards

International Accounting Standards

International Organization of Securities Commissions

Jamaica Clearing Bankers Association

Jamaica Central Securities Depository 
JDIC

JSE

LVTS

MAT

MCCSR

MFP

MOF

MOU

NCB

$\mathrm{OMO}$

OTC

PBMA

POS

QMPR

RTGS

SDDS

WHF
Jamaica Deposit Insurance Corporation

Jamaica Stock Exchange

Large Value Transfer System

minimum asset test

Minimum Continuing Capital and Surplus Requirement

Monetary and Financial Policies

Ministry of Finance

Memorandum of Understanding

National Commercial Bank

open market operations

over the counter

Public Bodies Management and Accountability Act

Point of sale

Quarterly Monetary Policy Report

Real Time Gross Settlement

Special Data Dissemination Standard

Western Hemisphere Payments and Securities Clearance and Settlement Forum 


\section{Key Points And Macro-Relevant Recommendations}

1. Jamaica has considerably strengthened financial system oversight following a costly financial crisis in 1996-97. The financial system is deep and well-developed, the regulatory framework has in many respects been brought into line with best international practices, and supervision appears to be implemented in a systematic and professional manner. Remaining regulatory gaps and weaknesses in the financial infrastructure are well recognized by the authorities, who have implemented important reforms. Regulatory capital has also increased in most financial institutions to levels that permit a reasonable degree of resilience against macroeconomic shocks. However, data limitations prevented a full system-wide quantitative analysis of risks.

2. Financial institutions operate in a risky environment. The very large public debt (135 percent of GDP at end-September 2005), coupled with weak underlying economic growth, is an overarching vulnerability for the economy and constrains macroeconomic policy options. Partly because of this, disturbances originating either at home or abroad can potentially lead to large swings in interest and exchange rates. Natural disasters (notably hurricanes) are also endemic to the region. And stock prices and (anecdotally) housing prices have risen sharply.

3. Financial institutions are closely linked via conglomerate structures and common exposure to domestic public debt. Conglomerates dominate the financial system thereby necessitating supervisors to be carefully attuned to risks of multiple gearing of capital, connected lending, conflicts of interest, and regulatory arbitrage. Even with proper arms length separation between bank and nonbank group members, reputational risks could be a source of contagion. Sizable public debt holdings by all financial institutions mean that the stability of the financial system as a whole is closely bound to the sustainability of the macroeconomic environment. This further underscores the authorities' policy priority of reducing the public debt.

4. Against this background, a key challenge for supervisors is to constantly align regulations with industry developments and strengthen the weakest links. The rapid growth of securities dealers has posed a specific challenge in recent years. Securities dealers are vulnerable to interest rate and liquidity shocks and insolvencies could undermine confidence in the industry with potentially adverse consequences for the government bond market. The authorities are cognizant of the risks and have been strengthening the prudential framework for dealers. But more needs to be done to fortify the capital regime, and reduce legal, operational and settlement risks. At a more general level, supervisory agencies will likely need more resources and budgetary flexibility to attract and retain qualified staff. Some aspects of their operational independence should also be strengthened in the law.

5. The dominance of conglomerates accords urgency to the need to develop a more consolidated approach to supervising the financial system. Modifications to the legal framework, including passage of a proposed Omnibus Banking Bill, would enable the supervisory authorities to better implement consolidated supervision. But strengthening inter-agency cooperation is at least as important. The creation in 2001 of a high-level forum for the supervisory agencies, the Financial Regulatory Council (FRC), was an important step 
forward in this regard. However, the FRC needs to become more active in formalizing cooperative relations among agencies, forging the prudential framework for conglomerates, encouraging more analysis of group risks, and testing crisis management systems. The appointment of lead supervisors would considerably facilitate this. Down the road, it may be more efficient to organize the limited supervisory resources under a unified agency.

6. A development priority is to foster access to credit. While fiscal crowding out is partly responsible for a relatively low credit/GDP level, a better insolvency and creditor rights system and establishment of a credit bureau would strengthen credit supply conditions. Planned Bank of Jamaica (BoJ) supervision of credit unions will also need to preserve the extensive outreach of credit unions to small savers and borrowers under an appropriately designed risk-based system.

7. The authorities should complement their recently enacted, sound legal framework for pensions with a regulatory regime that protects consumers and encourages participation. The regulations need to emphasize adequate minimum solvency requirements for defined-benefit plans and a disclosure-oriented approach for defined-contribution plans. Unequal tax treatment of employer-independent retirement schemes should be quickly corrected. Parliament should rapidly approve making the Financial Services Commission (FSC) the regulator of pensions.

8. Some key infrastructure weaknesses require prompt attention. The payments system has poor legal foundations and technical deficiencies. Introducing, as planned, an appropriate legal framework and real time gross settlement (RTGS) system is therefore a priority. Another important infrastructure weakness is the lack of a central securities depository (CSD) for fixed-income securities, especially given the large volume of government paper.

9. Box 1 summarizes the main macro-relevant recommendations. Considerable progress could be made in all areas over the course of the next two years, with many measures being put in motion immediately. In addition to several technical notes, detailed recommendations were provided to the authorities based on assessments of adherence to the Basel Core Principles (BCP) for Effective Banking Supervision, the CPSS Core Principles for Systemically Important Payments Systems, the IMF's Monetary and Financial Policy Transparency code, and the World Bank's standards for Insolvency and Creditor Rights (see Annex). 


\section{Box 1. Key Macro-Relevant Recommendations}

\section{Maintaining financial stability and enhancing supervision:}

Reduce the public debt.

Raise margin requirements on securities dealers' repos in GoJ securities to at least 10 percent this year.

Strengthen monitoring and analysis of housing and equities prices.

Enhance analysis of insurance risk concentration and reinsurance coverage.

Develop and test crisis management plans.

Strengthen coordination across supervisory agencies and close remaining legal gaps (including through passage of an Omnibus Banking bill) to permit comprehensive consolidated supervision and more effective supervision of conglomerates.

Give supervisory agencies more resources and budgetary flexibility.

Further codify the legal and operational independence of supervisory agencies.

\section{Addressing development and infrastructure priorities:}

Overhaul creditor rights and the insolvency regime and introduce a credit bureau.

Ensure that the new regulatory regime for credit unions is carefully balanced to minimize risks without stifling credit unions' impressive outreach.

Pass legislation to enable FSC to begin registering and regulating pension funds; equalize the income tax treatment of approved retirement schemes with that of superannuation funds.

Expedite introduction of a sound legal framework for payment and settlement systems; introduce an RTGS system.

Establish a CSD for fixed income securities.

\section{BACKGROUND}

\section{Financial sector structure and developments}

\section{A costly financial crisis in 1996-97 helped shape the current financial system.}

Key ingredients of the crisis were financial liberalization, regulatory arbitrage, and management and governance failures in several financial firms. Institutions pursued aggressive growth strategies, relying on short-term deposits or deposit-like instruments to fund longer-term investments and lend to connected parties. Subsequent monetary tightening 
squeezed liquidity and, as perceived risks escalated, depositors and investors withdrew funds. The crisis cost some 40 percent of GDP and ushered in consolidation in the banking and insurance sectors. To improve supervision of nonbanks, the FSC became operational in 2002, while the BoJ retained supervision of deposit-taking institutions.

\section{Jamaica's financial system is large and interconnected, with reasonably} well-developed markets. Total assets amount to about 185 percent of GDP, with all segments of an advanced financial system present and closely interconnected via a handful of dominant conglomerates (Tables 1 and 2). Several have foreign parent companies or overseas activities, and the parent of one domestic conglomerate is an industrial company. Jamaica has active primary and secondary markets for government bonds, an automated stock exchange for equities, a deep repo-based money market, an active (though small) market for short-term commercial paper, and a spot market for foreign exchange. The stock market has benefited from the development of the Jamaica Central Securities Depository, which has facilitated an increase in trading and transfer of shares between Jamaica and the central securities depositories (CSDs) in Trinidad and Tobago and Barbados. But the number of listings (41) remains small and market liquidity low. Bonds are traded in an OTC market with transfers manually recorded and delivered.

\section{A major activity of all financial institutions is to intermediate the large public}

debt. More than half of the public debt is held by domestic financial institutions (Figure 1). A persistently large public debt crowds-out private credit, which even before the crisis was only around 25 percent of GDP (Figure 2). Credit growth has been growing quite sharply in recent years, but from a low base following earlier write-offs. As a share of GDP, it remains low by the standards of many countries of comparable per capita income (Figure 3 ).

\section{The salient development of recent years has been the rapid growth of the} security dealers sector. A number of factors have played a role in this growth, including the increased issuance of securitized debt, deregulation of the industry to allow retailers to participate, the yield pick up in government paper relative to bank deposits, and legislation in 2002 to separate banking from non-banking activities, which resulted in the large transfer of funds under management (FUM) from merchant banks to less-regulated securities dealers. Dealers' assets and FUM now exceed the deposit base of commercial banks.

\section{The emergence of the securities dealers has facilitated the development of}

financial and capital markets. Dealers have provided a market for government bonds and enhanced the liquidity of secondary markets, thereby helping to provide a more stable source of government funding. They have also encouraged the participation of retail investors (about half of dealers' FUM are with retail clients) in their funding via repo instruments, diversifying risks more directly to the public while also permitting more choice for investors in terms of both number of institutions and variety of investment vehicles.

\section{At the same time, the dealers pose new risks that the supervisors have been}

trying to catch up with. Dealers mainly finance their long-term investments with repos of very short-term maturities with retail and institutional clients, exposing dealers to interest rate and liquidity risks. Further, because the instruments and transactions are more complex, 
Table 1. Financial System Structure, 1995-2004

(Total assets in million Jamaican dollars)

\begin{tabular}{|c|c|c|c|c|}
\hline & 1995 & 2000 & 2003 & $20042 /$ \\
\hline \multicolumn{5}{|l|}{ Commercial banks } \\
\hline Number of institutions & 11 & 6 & 6 & 6 \\
\hline Total assets & 121,325 & 221,705 & 313,516 & 344,379 \\
\hline Percent share to total financial sector assets 3 / & $\ldots$ & $\ldots$ & $\ldots$ & 33.5 \\
\hline \multicolumn{5}{|l|}{ Merchant banks } \\
\hline Number of institutions & 25 & 14 & 7 & 5 \\
\hline Total assets & 17,334 & 7,680 & 44,102 & 50,615 \\
\hline Percent share to total financial sector assets 3 / & $\ldots$ & $\ldots$ & $\ldots$ & 4.9 \\
\hline \multicolumn{5}{|l|}{ Building Societies } \\
\hline Number of institutions & 32 & 5 & 4 & 4 \\
\hline Total assets & 29,084 & 44,290 & 66,679 & 80,590 \\
\hline Percent share to total financial sector assets $3 /$ & $\ldots$ & $\ldots$ & $\ldots$ & 7.8 \\
\hline \multicolumn{5}{|l|}{ Credit unions } \\
\hline Number of institutions & 82 & 60 & 52 & 50 \\
\hline Total assets & 4,098 & 14,643 & 23,834 & 28,529 \\
\hline Percent share to total financial sector assets 3 / & $\cdots$ & $\cdots$ & $\cdots$ & 2.8 \\
\hline \multicolumn{5}{|l|}{ Financial houses and trust companies } \\
\hline Number of institutions & 4 & $\ldots$ & $\ldots$ & $\ldots$ \\
\hline Total assets & 639 & 816 & 7,610 & 1,167 \\
\hline Percent share to total financial sector assets $3 /$ & $\ldots$ & $\ldots$ & $\ldots$ & 0.1 \\
\hline \multicolumn{5}{|l|}{ Life Insurance companies } \\
\hline Number of institutions & 12 & 8 & 7 & 7 \\
\hline Total assets & $\ldots$ & 32,326 & 51,158 & 68,199 \\
\hline Percent share to total financial sector assets 3 / & $\ldots$ & $\ldots$ & $\ldots$ & 6.6 \\
\hline \multicolumn{5}{|l|}{ Non-Life Insurance companies } \\
\hline Number of institutions & $\ldots$ & 17 & 14 & 13 \\
\hline Total assets & $\ldots$ & 12,506 & 26,968 & 40,360 \\
\hline Percent share to total financial sector assets 3 / & $\ldots$ & $\ldots$ & $\ldots$ & 3.9 \\
\hline \multicolumn{5}{|l|}{ Unit Trust Funds } \\
\hline Number of institutions & $\ldots$ & $\ldots$ & 4 & 10 \\
\hline Total assets & $\ldots$ & $\ldots$ & $\ldots$ & 13,686 \\
\hline Percent share to total financial sector assets $3 /$ & $\ldots$ & $\ldots$ & $\ldots$ & 1.3 \\
\hline \multicolumn{5}{|l|}{ Securities Firms } \\
\hline Number of institutions & $\ldots$ & $\ldots$ & $\ldots$ & 30 \\
\hline Total assets & $\ldots$ & $\ldots$ & 278,029 & 300,667 \\
\hline Percent share to total financial sector assets 3 / & $\ldots$ & $\ldots$ & $\ldots$ & 29.3 \\
\hline \multicolumn{5}{|l|}{ Pension Funds 4/ } \\
\hline Number of institutions & $\ldots$ & $\ldots$ & $\ldots$ & \\
\hline Total assets & $\ldots$ & $\ldots$ & $\ldots$ & 98,533 \\
\hline Percent share to total financial sector assets $3 /$ & $\ldots$ & $\ldots$ & $\ldots$ & 9.6 \\
\hline Total Assets & $\ldots$ & $\ldots$ & $\ldots$ & $1,026,725$ \\
\hline Percent of GDP & $\ldots$ & $\ldots$ & $\ldots$ & 184.6 \\
\hline
\end{tabular}

Sources: Bank of Jamaica, Financial Services Commission, and Staff estimates.

1/ Financial sector assets are not consolidated.

2/ Starting 2004, assets are defined as net of provisions for losses consistent with International Financial

Reporting Standards (IFRS).

3/ Total financial sector assets include combined assets of only the sectors covered in this table.

4/ Based on survey results conducted by the FSC as of March 2004. 


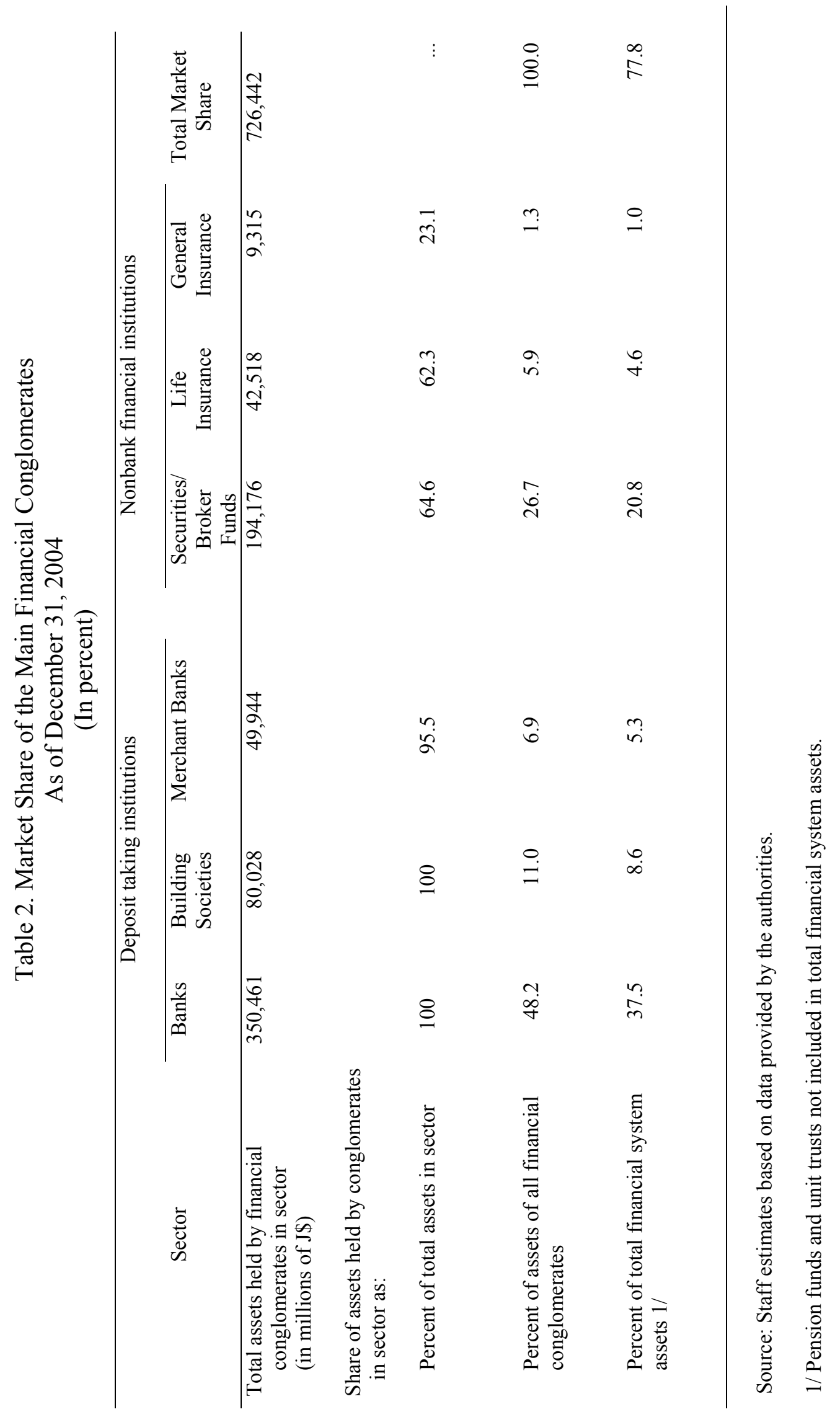


investors face increased exposure to operational and legal risks including mis-selling and fraud. Settlement risk is also heightened by the reliance on paper securities and delays in establishing the CSD. On the one hand, failures in small dealers could lead to welcome consolidation in the sector. But dealer failure would test uncharted legal questions about investors' rights to title (notwithstanding the securitized nature of the repo instruments), risking a loss of confidence in the sector. A rapid unwinding of repos would affect the liquidity position of the dealers and create a major disruption to government financing. So far, the industry has expanded without loss of customer funds.

\section{Economic conditions}

16. The vulnerabilities stemming from high public indebtedness aside, current economic conditions are generally stable, although interest and exchange rates have exhibited considerable volatility in the recent past. In the first half of 2003, capital outflows and strong downward pressure on the exchange rate prompted steep rises in interest rates to over 30 percent (Figure 4). But subsequent exchange rate stability enabled 6-month interest rates to be brought down to 13 percent at end-2005. Inflation excluding volatile food and energy prices averaged just over 10 percent in 2005 . Stock prices have quadrupled since 2000, albeit after being subdued for several years, increasing $\mathrm{P} / \mathrm{E}$ ratios to around 15 from the 6-9 range, and raising market capitalization to 150 percent of GDP. ${ }^{1}$ Anecdotal evidence also suggests a run up in property prices, but no official data are maintained.

17. Economic growth remains subdued. For a long period, growth has averaged little more than 1 percent a year (Table 3). Weak growth has made fiscal consolidation an uphill challenge, although the budget deficit has been significantly reduced in recent years. Hurricanes are endemic to the Caribbean and active seasons in 2004 and 2005 caused significant damage, disrupted output, and added to fiscal costs.

\footnotetext{
${ }^{1}$ About half the capitalization reflects foreign-listed firms. Domestic listings have slightly outperformed the full JSE index.
} 


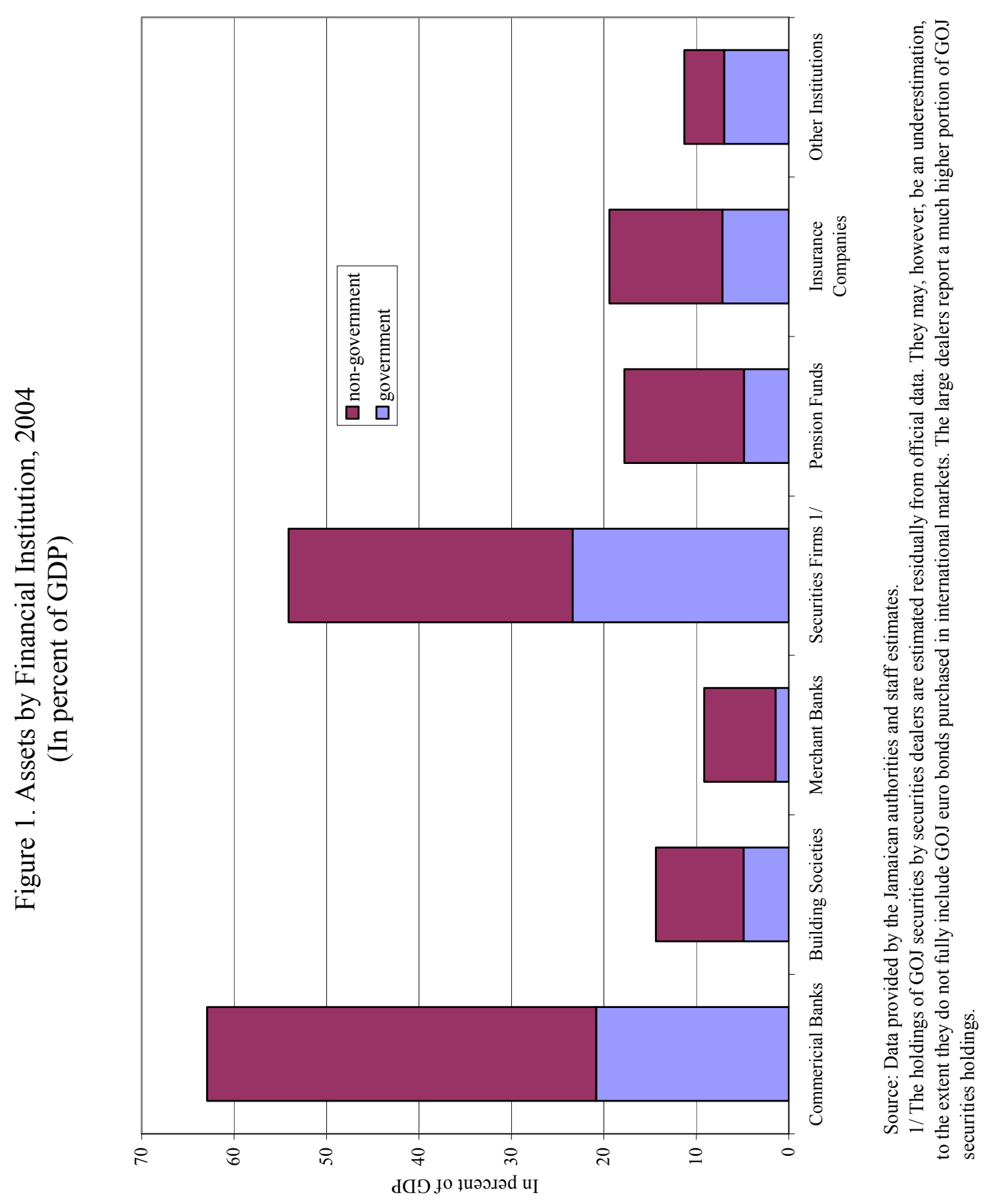




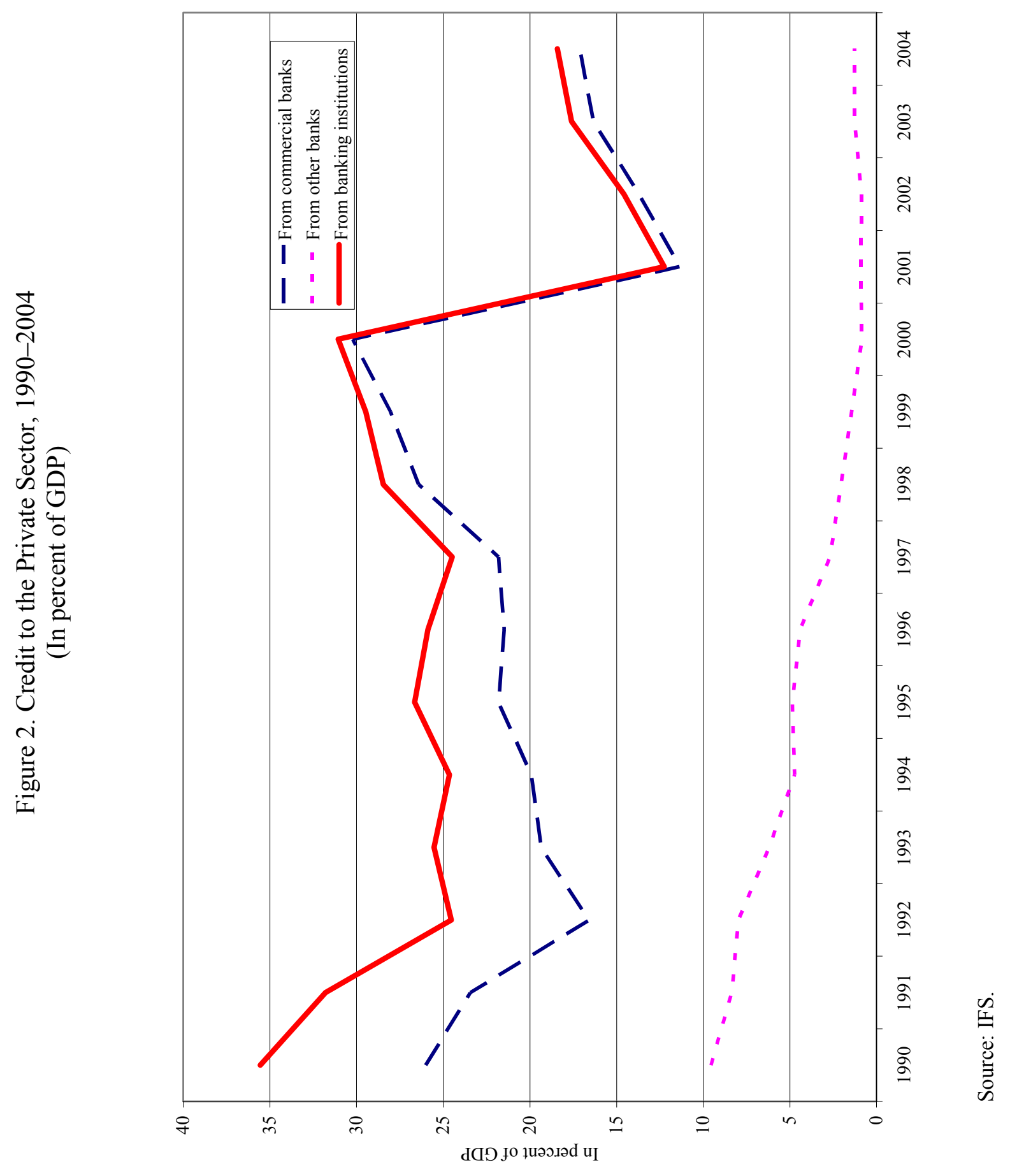




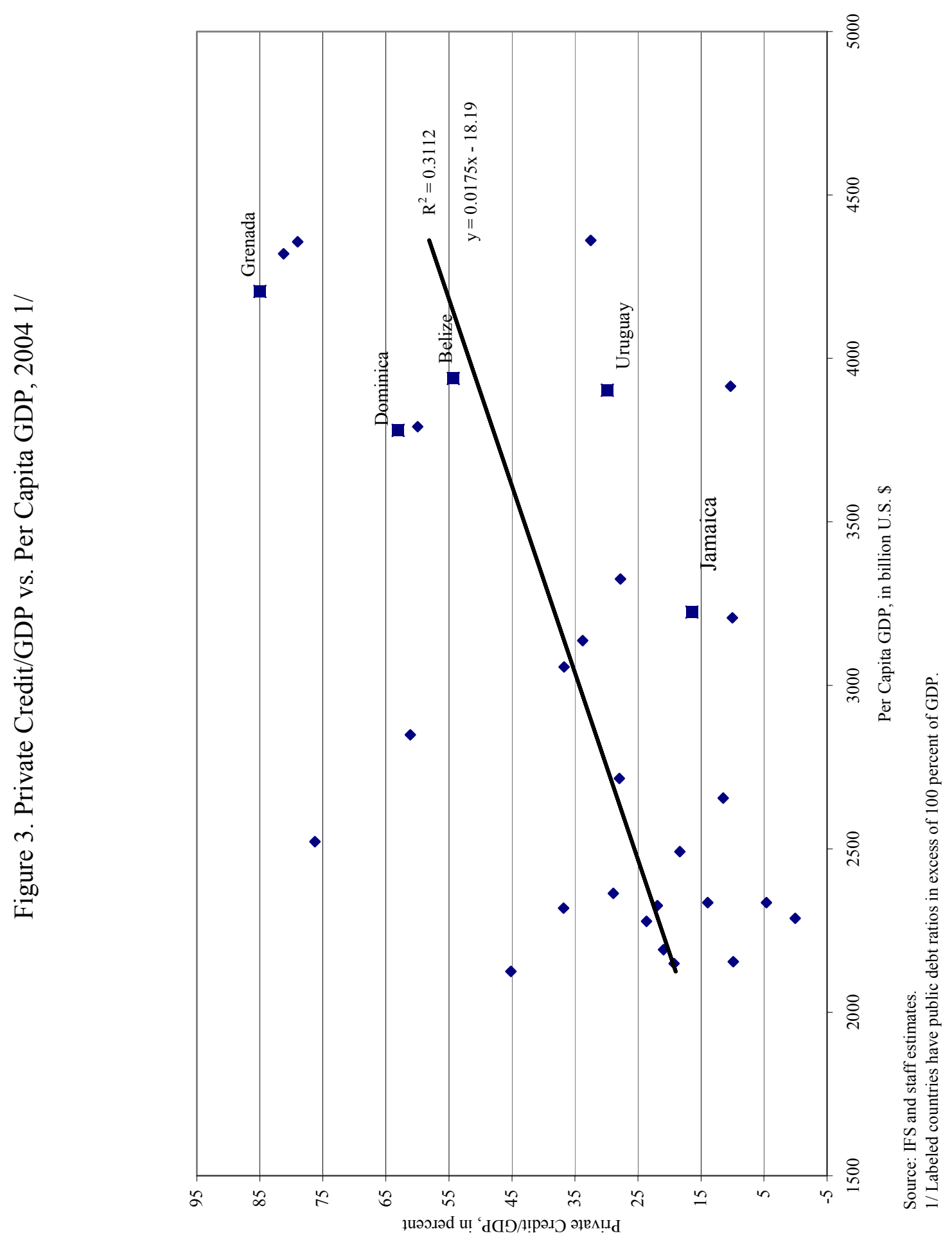


Figure 4. Exchange Rates and Selected Interest Rates

Selected Interest Rates, 2000-05

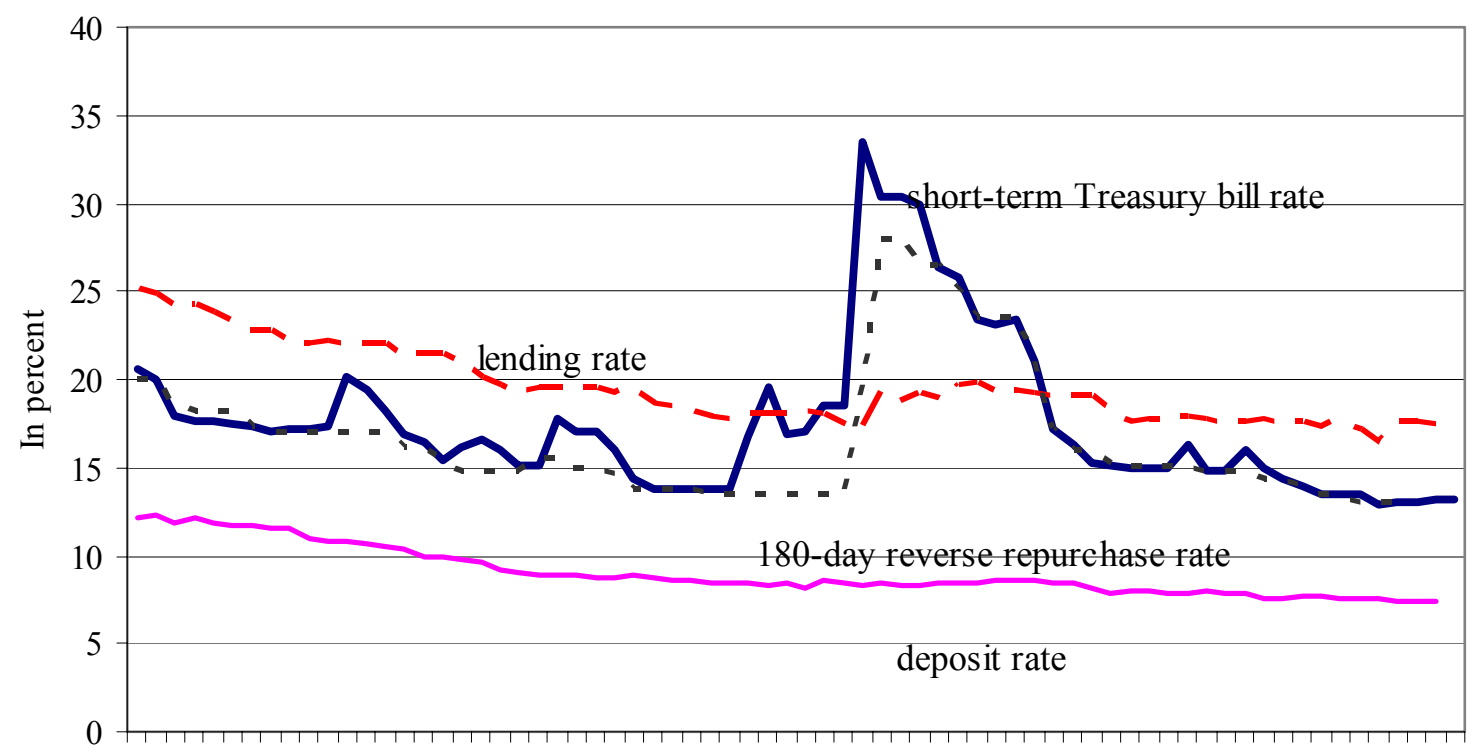

2000M1 2000M7 2001M1 2001M7 2002M1 2002M72003M1 2003M7 2004M1 2004M7 2005M1 2005M7

Exchange Rates, 2000-05

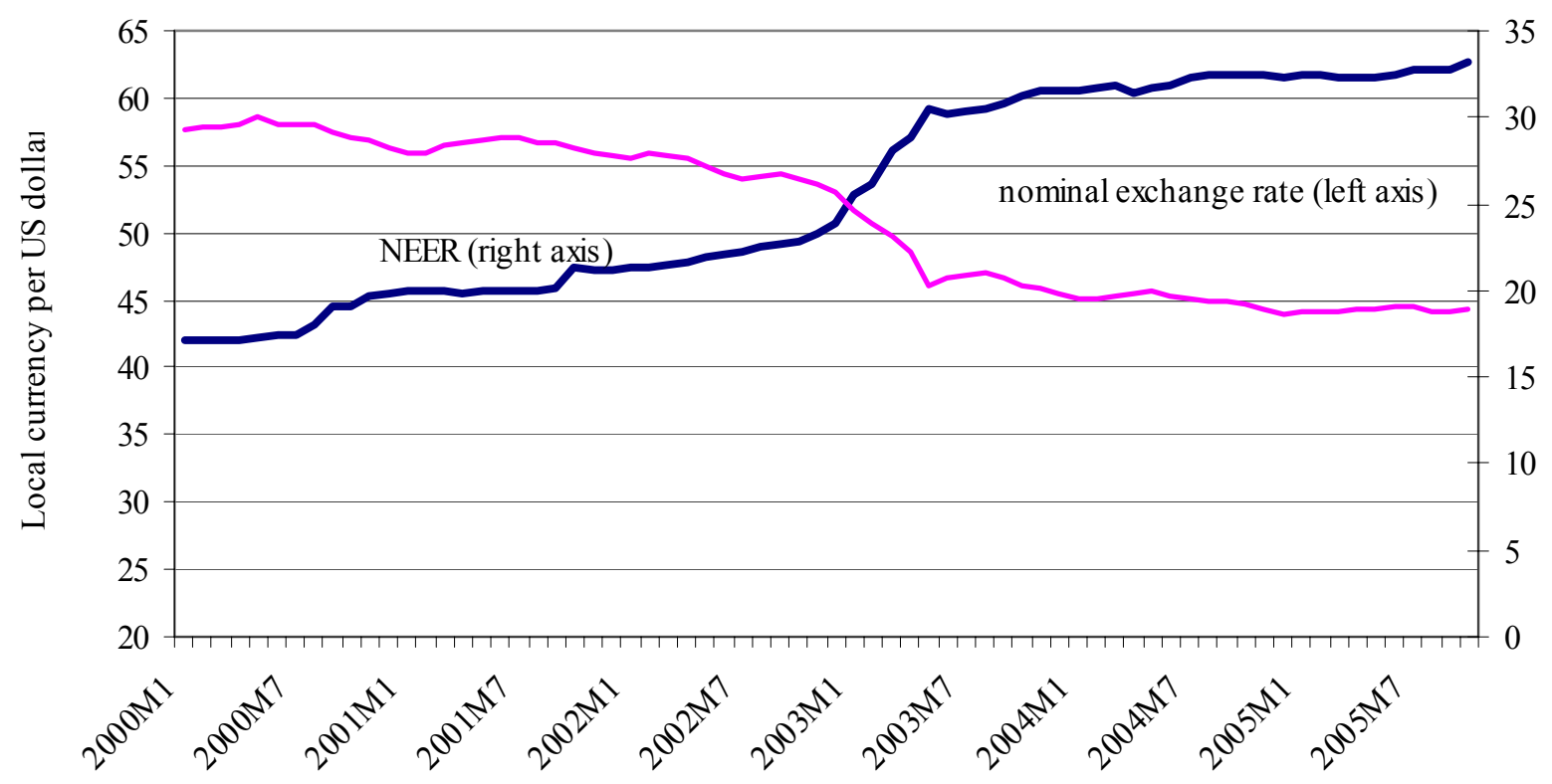

Sources: IFS and Jamaican authorities. 
Table 3. Jamaica: Selected Economic Indicators 1/

\begin{tabular}{|c|c|c|c|c|c|}
\hline & $2000 / 01$ & $2001 / 02$ & $2002 / 03$ & $2003 / 04$ & $2004 / 05$ \\
\hline & \multicolumn{5}{|c|}{ (Annual percentage changes) } \\
\hline \multicolumn{6}{|l|}{ GDP, prices, and employment } \\
\hline Real GDP & 0.8 & 0.9 & 2.2 & 1.9 & 0.4 \\
\hline Nominal GDP & 11.6 & 9.5 & 10.0 & 18.9 & 12.1 \\
\hline Consumer price index (end of period) & 6.4 & 7.6 & 6.2 & 16.8 & 13.2 \\
\hline Consumer price index (average) & 7.7 & 8.0 & 6.5 & 12.9 & 12.7 \\
\hline Exchange rate (end of period, in J\$/US\$) & 8.3 & 4.0 & 17.9 & 1.7 & 0.9 \\
\hline \multicolumn{6}{|l|}{ End-of-period REER (percent change, } \\
\hline \multirow[t]{2}{*}{ Unemployment rate (in percent) } & 15.5 & 14.8 & 14.2 & 11.8 & 12.2 \\
\hline & \multicolumn{5}{|c|}{ (In percent of GDP, unless otherwise indicated) } \\
\hline \multicolumn{6}{|l|}{ Government operations } \\
\hline Budgetary revenue & 29.1 & 27.0 & 28.1 & 29.4 & 30.8 \\
\hline Budgetary expenditure & 33.6 & 32.6 & 35.7 & 36.0 & 35.7 \\
\hline Primary expenditure & & 19.2 & 20.8 & 18.2 & 19.1 \\
\hline Interest payments & 16.0 & 13.4 & 14.9 & 17.8 & 16.7 \\
\hline Budget balance & -4.5 & -5.6 & -7.6 & -6.6 & -4.9 \\
\hline Of which: primary fiscal balance & 11.5 & 7.8 & 7.3 & 11.2 & 11.7 \\
\hline Off-budget expenditure 3 / & 0.3 & 0.5 & 3.2 & 3.1 & 2.2 \\
\hline Overall fiscal balance & -4.8 & -6.1 & -10.8 & -9.7 & -7.1 \\
\hline Public debt 4/ & 132.0 & 135.1 & 148.0 & 143.7 & 137.9 \\
\hline \multicolumn{6}{|l|}{ External sector } \\
\hline Current account balance & -6.7 & -9.2 & -15.2 & -6.8 & -6.1 \\
\hline Of which: exports of goods, f.o.b. & 20.6 & 17.5 & 17.2 & 17.7 & 17.2 \\
\hline Of which: imports of goods, f.o.b. & 41.4 & 36.8 & 43.8 & 39.7 & 40.5 \\
\hline \multirow[t]{2}{*}{ Net international reserves (in millions of US\$) } & 1,286 & 1,942 & 1,340 & 1,569 & 1,902 \\
\hline & \multicolumn{5}{|c|}{ (Changes in percent of beginning of period broad money) $5 /$} \\
\hline \multicolumn{6}{|l|}{ Money and credit } \\
\hline Net foreign assets $5 /$ & 23.0 & 24.3 & -8.1 & 9.0 & 7.5 \\
\hline Net domestic assets & -13.8 & -14.3 & 15.6 & 11.3 & 2.7 \\
\hline Of which: credit to the central government & 0.8 & 71.2 & 8.2 & 9.7 & 0.5 \\
\hline Broad money & 9.2 & 10.0 & 7.5 & 20.2 & 10.3 \\
\hline Private sector credit growth $1 /$ & 18.6 & -56.7 & 30.5 & 38.9 & 18.7 \\
\hline Velocity (ratio of GDP to broad money) & 2.4 & 2.6 & 2.7 & 2.6 & 2.6 \\
\hline \multicolumn{6}{|l|}{ Memorandum items: } \\
\hline $\begin{array}{l}\text { Nominal GDP (in billions of Jamaican } \\
\text { dollars) }\end{array}$ & 346.8 & 380 & 418 & 497 & 556 \\
\hline Exchange rate (end of period, J\$/US\$) & 45.7 & 47.6 & 56.2 & 60.8 & 61.5 \\
\hline
\end{tabular}

Sources: Jamaican authorities; IFS; and Fund staff estimates and projections.

1/ Based partly on assumptions provided by the authorities. Fiscal years run from April 1 to March 31 .

2/ Original projections for FY 2005/06, as reported in IMF Country Report No. 05/219.

3 / Includes issuance of debt to the BoJ to cover its cash losses and related capitalized interest, and debt related to off-budget projects related to off-budget projects financed initially by the private sector.

4/ Excluding financing flows associated with the PetroCaribe agreement.

5/ Including valuation adjustments.

6/ January-December annual data from IFS. 


\section{Sectoral ASSESSMents}

\section{A. Deposit Taking Institutions (DTIs)}

\section{Structure of the sector ${ }^{2}$}

\section{Three types of DTI are supervised by the BoJ under a common regulatory}

framework. The most important are the six commercial banks, with two banks accounting for about three fourths of the assets. All commercial banks are members of broader financial groups and five, representing 97 percent of commercial bank assets, have foreign parents. The other DTIs are merchant banks and building societies. The latter specialize in mortgage lending.

\section{Commercial bank profitability is perhaps helped by low competition and the} perceived safe-haven of some banks. The existence to some extent of a captive market for deposits keeps deposit rates significantly below returns on investment products offered by securities dealers and insurance companies - although such products also carry higher risk premiums and are not backed by deposit insurance. In combination with fiscal crowding-out and poor supply conditions for lending, which together keep lending rates high, lending-deposit spreads are thus high compared with other highly-indebted countries (Table 4). In addition, a mainstay of banks' profitability are sizable portfolio earnings: with about a quarter of their total assets in GoJ securities, banks' estimated annual income from government securities amounts to about 35 percent to 40 percent of their regulatory capital.

Table 4. Comparison of Interest Rate Spreads, 2000-05 ${ }^{1 /}$

\begin{tabular}{lrrrrrr}
\hline & 2000 & \multicolumn{1}{c}{2001} & \multicolumn{1}{c}{2002} & 2003 & 2004 & $2005^{2 /}$ \\
\hline St. Kitts & 6.8 & 6.8 & 6.9 & 7.7 & 5.7 & 5.6 \\
Dominica & 7.8 & 7.2 & 7.1 & 7.8 & 5.7 & 7.3 \\
Grenada & 7.4 & 6.0 & 7.7 & 8.7 & 6.9 & 7.4 \\
Philippines & 2.6 & 3.7 & 4.5 & 4.3 & 3.9 & 5.1 \\
Argentina & 2.7 & 11.5 & 12.4 & 9.0 & 4.2 & 2.2 \\
Lebanon & 6.9 & 6.3 & 5.5 & 4.7 & 3.4 & 2.7 \\
Belize & 8.3 & 9.1 & 8.6 & 7.4 & 6.5 & 6.7 \\
Uruguay & 27.8 & 27.0 & 55.8 & 29.3 & 17.5 & 10.7 \\
Jamaica & $\mathbf{1 3 . 2}$ & $\mathbf{1 1 . 9}$ & $\mathbf{1 1 . 4}$ & $\mathbf{1 2 . 6}$ & $\mathbf{1 1 . 7}$ & $\mathbf{1 2 . 0}$ \\
\hline
\end{tabular}

Source: IFS, Jamaican authorities, and staff calculations.

$1 /$ Spreads are defined as the difference between lending and deposit rates.

2/ As of September 2005.

\footnotetext{
${ }^{2}$ Not included in the sector are three development banks, which do not take deposits and which are supervised by various ministries. A case can be made for bringing some of them under the supervision of the BoJ, particularly the Jamaica Mortgage Bank, which has potentially risky exposure to property development and mortgage insurance, although its balance sheet is relatively modest.
} 
20. Credit unions are currently self-regulated and have extensive outreach. With some 760,000 members (about 60 percent of the adult population), the penetration rate of credit unions is among the highest in the world. Savings held by credit unions equivalent to about 4 percent of GDP are not large compared to banking system deposits, but credit union members are more numerous than bank depositors and the number of credit union loans exceeds that of bank personal loans. Rapid growth has made the larger credit unions appear increasingly like conventional banks. Credit unions are regulated by the Jamaica Cooperative Credit Union League Limited, which also plays the role of industry advocate, savings insurer (through its Stabilization Fund), lender of last resort, and provider of services to smaller credit unions. The BoJ is expected to take over their supervision in 2006.

\section{Financial soundness}

21. Financial soundness indicators for banks have strengthened in recent years. At end-September 2005, estimated aggregate capital adequacy for the banking system was about 19 percent compared to the 10 percent prudential requirement, return on assets was running at a high rate by international standards, and the ratio of liquid assets to total deposit liabilities was well above prudential requirements (Table 5). ${ }^{3}$ Reported NPLs have shrunk significantly since the crisis to about 3 percent (Figure 5).

22. Stress tests conducted jointly with the BoJ suggest that most DTIs would be resilient to a variety of single factor shocks. As discussed in more detail in Appendix, large interest rate hikes could potentially be damaging, particularly for some building societies depending on the limits to their ability to pass on higher rates to borrowers. However, DTIs could withstand large increases in NPLs (three- to fourfold) before capital fell significantly below required levels. And regulatory capital is conservatively defined so that most banks have some buffer capital consisting of retained earnings and unrealized portfolio gains. Exchange rate vulnerability appears small in isolation although a sharp depreciation could be potentially damaging if followed by large interest rate hikes. Vulnerability to severe housing price declines is a potential concern, especially given that property is the main form of collateral. More careful evaluation and the collection of price and other relevant data on exposures are strongly recommended. ${ }^{4}$

\footnotetext{
${ }^{3}$ Zero risk-weight is assigned to government securities. However, even with a 100 percent risk-weighting, CARs for banks would range from 6 percent to 23 percent, with only one commercial bank and one merchant bank falling below the 10 percent minimum.

${ }^{4}$ Loans above two-thirds of property value are typically insured by the borrower through the Jamaica Mortgage Bank thus transferring some of the risk away from building societies. The ultimate guarantor of the Jamaica Mortgage Bank is the government.
} 


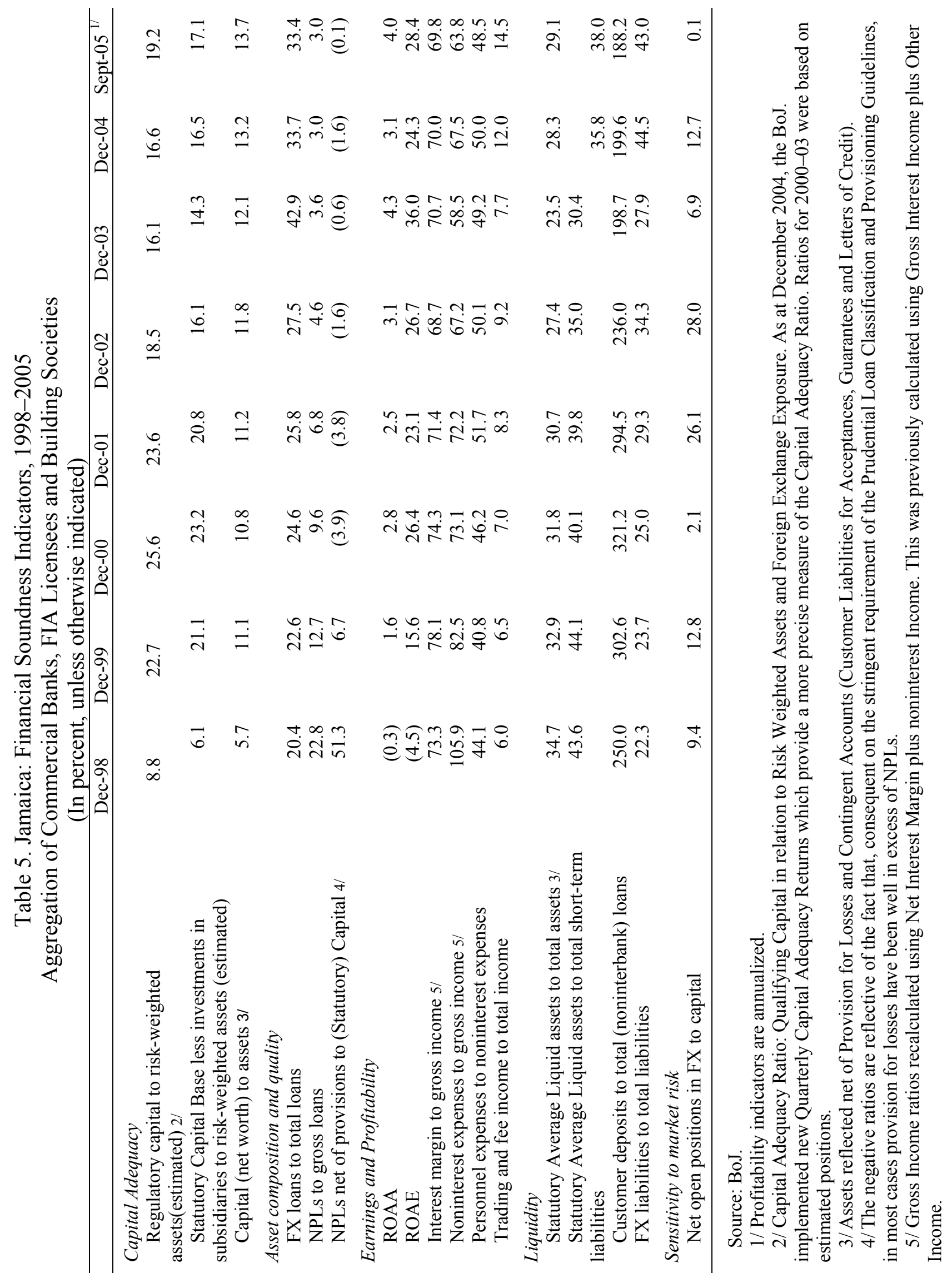




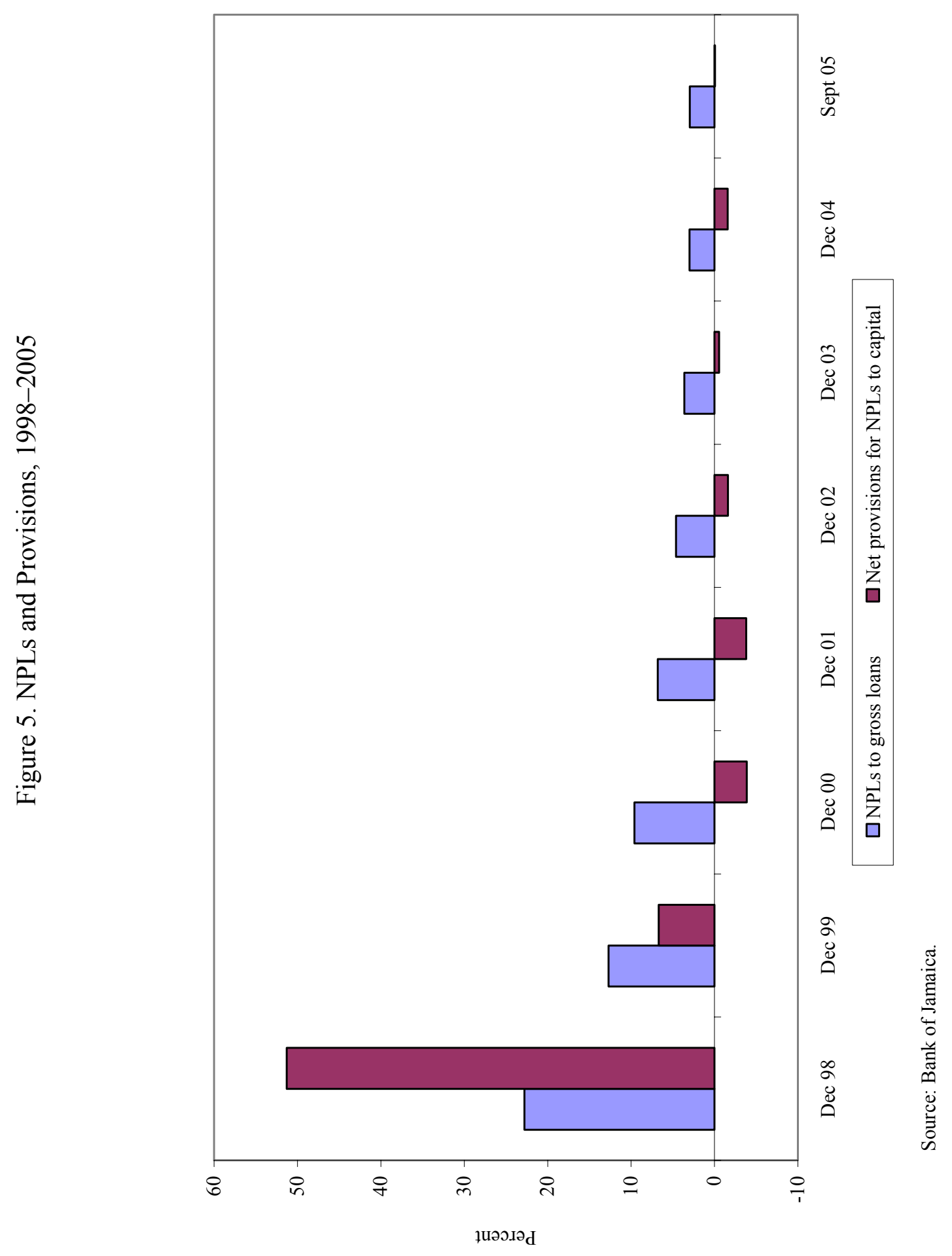




\section{Supervisory and regulatory assessment}

23. The supervisory and regulatory framework for banking shows high compliance with international standards, albeit with some important gaps. The legal framework is generally sound and modern, the BoJ's system for supervision is comprehensive and professionally staffed, and accounting and financial disclosure standards are broadly in line with international standards. Supervisory capacity limits could, however, be tested with new mandates to supervise credit unions and money transfer systems, intensify supervision of financial conglomerates, and enhance anti-money laundering work. The implementation of consolidated supervision remains a challenge, notwithstanding much recent progress. ${ }^{5}$ And the concept of large exposures needs to be better described in the law in order to include all claims, including balance sheet and off-balance sheet items. Finally, the BoJ's independence in supervisory matters should be strengthened in the law: although in practice the BoJ acts independently, in principle the BoJ Act gives the Minister of Finance final say on a number of important operational issues, including the granting or revocation of licenses and remedial actions. The authorities propose to address remaining weaknesses in the regulation and supervision of banks in an Omnibus Banking Bill, which is being prepared.

24. The regulatory framework for credit unions will need to balance appropriate prudential standards, especially for the larger credit unions, with preserving access for small savers and borrowers. Among other provisions, the draft framework redefines credit unions' capital structure and introduces a new definition of unsecured credit, limited to 5 percent of assets and one percent of capital (20 percent of capital for very small institutions). A more conventional corporate structure would move credit unions away from their principle of member ownership and potentially curtail financial services secured on member shares. In addition, the proposed limit on unsecured credit would restrict credit unions that lend against movable property and borrowers' income flow, thereby potentially curtailing loans (e.g., for working capital for small commercial operations) that have consistently outperformed conventional credit in Jamaica.

\section{B. Nonbank Financial Institutions}

\section{Structure of the sector}

25. The spectacular rise in the securities dealers should not obscure the fact that Jamaica also has a well-established insurance sector. Securities dealers dominate the nonbank sector with assets of over 50 percent of GDP. The 10 largest dealers, many of which are members of financial groups, manage about 70 percent of the sector's funds. But insurance sector assets are also sizable and premiums of about 5 percent of GDP are about twice the Latin America and Caribbean average. Both life and nonlife sectors are concentrated - the largest three companies account for 75 percent and 49 percent of their respective sector's assets — and ultimate control of the life sector rests predominantly abroad.

\footnotetext{
${ }^{5}$ In particular, the BoJ has been using powers to enforce holding company structures on conglomerates that contain a DTI. See also section IV.A below.
} 
More than half of the life sector's assets derive from savings products, which do not typically provide long-term interest rate guarantees. In two cases so-called bancassurance products are distributed through a banking parent. ${ }^{6}$ Some 90 percent of property insurance is reinsured, although most reinsurance contracts have event limits of 20 percent of the total amount insured. Such limits played a role in the downfall of a local insurer due to its concentration of business in the Cayman Islands, which was devastated by Hurricane Ivan in 2004. The company is being liquidated.

26. Private pensions are also long established, although data on pension funds are sparse. A 2004 FSC survey suggested that about one tenth of all households belong to a superannuation fund registered under the Income Tax Act. The older and larger of these schemes typically provide defined benefits, and hold average assets per member of 6-7 times per capita GDP.

\section{Financial soundness}

27. Both life and nonlife insurance have been profitable in recent years (Table 6). All life insurers considerably exceed required capital adequacy ratios, helped by the zero risk-weighting on investments in government paper. The nonlife segment is less well capitalized and in 2004 (a year of relatively destructive hurricanes) several nonlife companies fell below, or were only slightly above, target solvency levels.

28. Insurers' main vulnerabilities stem from interest rate risk and natural disasters. While data limitations prevented a full analysis via stress tests, interest rate hikes are likely the most important risk to life insurers as they could prompt policy holders of savings products to withdraw their funds and thereby generate a liquidity crunch. However, life insurers specializing in traditional insurance products, with the duration of their assets shorter than the duration of liabilities, would stand to gain from higher interest rates. Discussions with the industry indicated that the largest insurers employ reasonably well-developed risk management models and do not have significant foreign exchange exposures. For nonlife companies, concentrations of exposure to catastrophic risks combined with limits on reinsurance create the most significant concerns. Finally, all insurers have sizable holdings of GoJ bonds, with annual interest receipts equivalent to more than 5 percent of assets, exposing them to domestic sovereign risk.

\footnotetext{
${ }^{6}$ Their resemblance to pure intermediation products prompted the BoJ to prohibit such distribution in other cases and clarify that it would use powers under the BoJ Act to prevent issuance of similar products in foreign currency. Before allowing further expansion of sales through banking affiliates, insurers should demonstrate adequate risk management capabilities and full disclosure of the products' risks. They should be subject to strong supervisory oversight in both areas.
} 
Table 6. Insurance Indicators of Profitability and Soundness, 2001-04

(In percent)

\begin{tabular}{lcccc}
\hline & \multicolumn{3}{c}{ Profitability relative to: } & \multirow{2}{*}{ Insurance Solvency } \\
\cline { 2 - 4 } & $\begin{array}{c}\text { Net } \\
\text { Premiums }\end{array}$ & $\begin{array}{c}\text { Capital and } \\
\text { Surplus }\end{array}$ & $\begin{array}{c}\text { Total } \\
\text { Assets }\end{array}$ & Measures ${ }^{1 /}$ \\
\hline Life Insurance & & & & \\
2001 & 27.1 & 30.2 & 4.5 & $337(1)$ \\
2002 & 30.0 & 30.4 & 5.8 & $333(0)$ \\
2003 & 43.8 & 30.1 & 7.1 & $368(0)$ \\
2004 & 42.5 & 28.3 & 6.9 & $406(0)$ \\
General & & & & \\
Insurance & & & & $130(3)$ \\
2001 & 12.2 & 14.9 & 4.1 & $152(1)$ \\
2002 & 23.1 & 26.2 & 6.4 & $153(0)$ \\
2003 & 36.9 & 35.0 & 8.8 & $170(3)$ \\
2004 & 3.5 & 4.1 & 0.6 & \\
\hline
\end{tabular}

Sources: FSC and staff estimates.

1/ Ratio of actual to required capital using minimum continuing capital and surplus requirement (MCCSR) for life and minimum asset test (MAT) for nonlife insurance expressed as percentage. Unweighted averages for sector. Note that by their construction, the two ratios are not directly comparable. The number of insurance companies below the minimum requirement of 100 percent in 2001-03 and 110 percent in 2004 parentheses.

29. For securities dealers, interest rate and liquidity risks are potentially sizable.

Balance sheet data for the 10 largest dealers for end-2004 revealed notable maturity mismatches based on earlier contractual repricing or maturity dates. These mismatches imply that an increase in interest rates of 5 percentage points (an amount well within historical experience) would have eroded capital by as much as 20 percent, with some dealers falling at least temporarily below the FSC's 6 percent minimum capital asset threshold. ${ }^{7}$ A portion of dealers' assets carry variable rates that reprice after six months (compared to repos that mostly reprice within 30 days). Such repricing is likely to offset a significant part of potential revenue losses. However, absence of a precise breakdown between fixed and floating rate securities, and other balance sheet data gaps, limited staff's ability to undertake comprehensive quantitative assessments of dealers' resilience to shocks.

30. Other risks to securities dealers appear less of a concern. Foreign exchange risk could be significant as a number of dealers hold dollar- and euro-denominated bonds. By contrast, credit risk due to investment in foreign or domestic corporate instruments and sovereign risk, other than GoJ, appears small.

\footnotetext{
${ }^{7}$ All dealers met all their obligations when interest rates spiked up by about 18 percentage points in 2003, but a number of dealers came under stress and some had to liquidate their securities inventory at considerable loss.
} 


\section{Improving risk management capabilities and strengthened prudential} requirements appear to be attenuating the risks. Discussions with market participants suggested that some dealers have developed, or are developing, sophisticated risk management systems and most were monitoring their interest rate exposures. FSC prudential requirements (see below) are also forcing dealers to increase their capital, which at end-2004 had only been slightly above minimum requirements for most dealers, and below for some (Table 7).

Table 7. Jamaica: Selected Indicators for Securities Firms

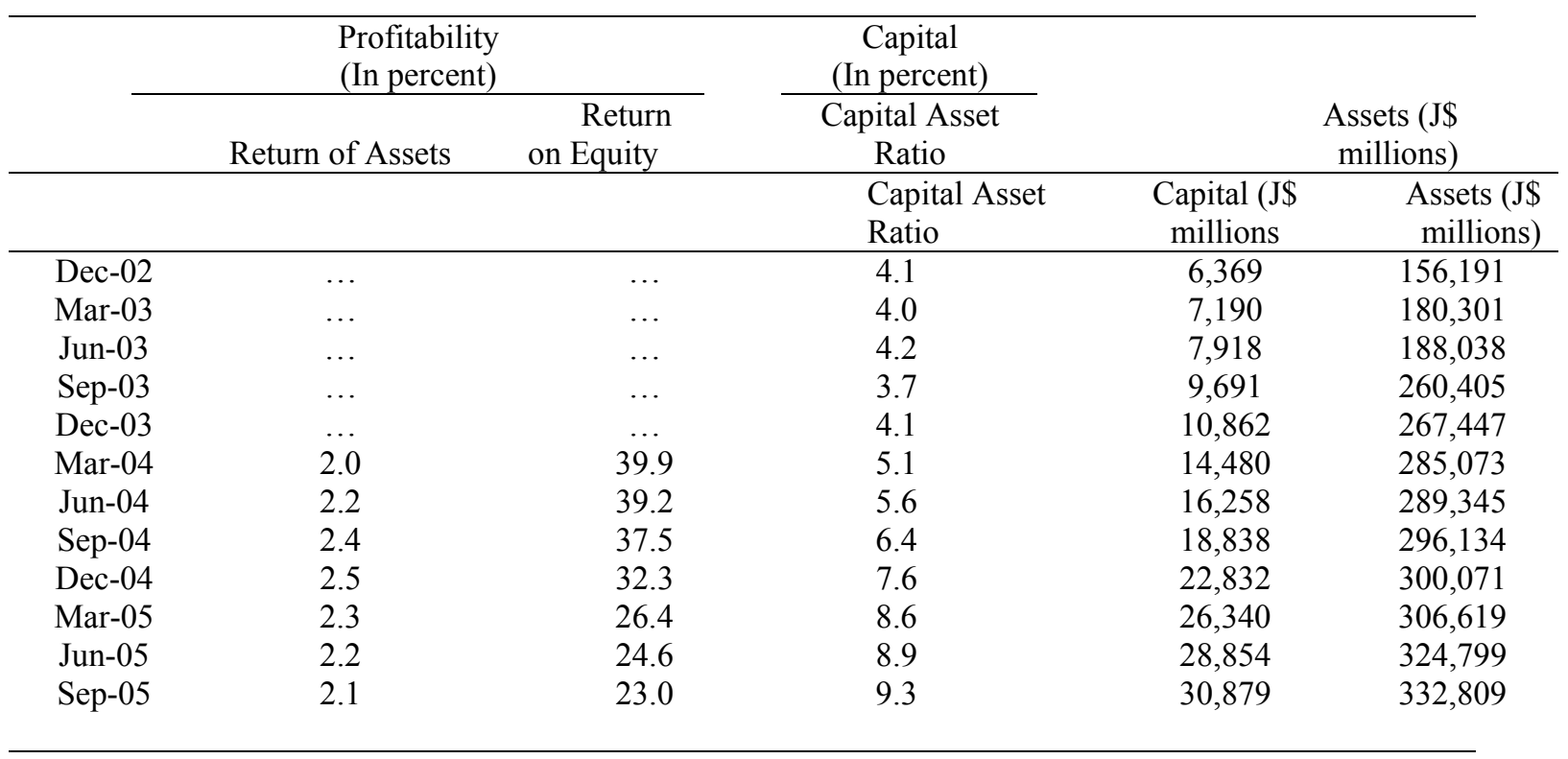

Source: Financial Services Commission.

32. The run-up in stock prices in a thinly-traded market has increased the potential for a reversal that could impact the financial system. Absence of comprehensive data on the investor base restricts analysis of the effect of a correction. Nonetheless, the investment portfolios of some financial institutions have significant shares in equities including private pensions (26 percent) and general insurance (13 percent). ${ }^{8}$ Private investors could also face losses and set back broader investor confidence in the market. With potential for market abuse given the industry structure, low market liquidity, and manual procedures for monitoring, the JSE and FSC should give priority to enhancing capabilities for collecting and monitoring market surveillance data.

\footnotetext{
${ }^{8}$ One building society has some 39 percent of its investment portfolio in equities, but corresponding sizable unrealized capital gains are not included in its regulatory capital.
} 


\section{Supervisory and regulatory assessment}

33. The FSC has quickly got up to operational speed. The regulatory and supervisory framework is broadly aligned with international best practices, although a number of needed refinements were identified in the detailed assessment work. With the ever growing sophistication of the insurance market, supervision rightly focuses on ensuring that companies have developed proper risk management systems and incentives to report their operations in a transparent manner. Prudential requirements seek to ensure sufficient capital coverage. On the securities side, the FSC's approach of combining prudential requirements and conduct of business rules that emphasize disclosure and governance structures, together with general improvements in accounting and valuation standards, have helped to strengthen the industry. In general, the FSC has a collaborative approach in dealing with institutions. This has benefits, but there is a need to guard against straying toward regulatory forbearance.

\section{FSAP recommendations emphasize the need to focus limited supervisory} resources on the key vulnerabilities. FSC staffing is approaching needed levels, but more budgetary flexibility would help to attract and retain qualified staff. The frequency of on-site inspections is insufficient and more emphasis needs to be placed on industry contacts, communication with other supervisory bodies within and outside Jamaica, and on monitoring the risk management practices of companies. ${ }^{9}$ At the same time, requirements on companies to provide information to supervisors - including stress tests - should be extended and enforced by penalties for noncompliance. For nonlife insurance, a priority is to strengthen the review and monitoring of reinsurance coverage. Finally, although the FSC has a high degree of independence, the Minister of Finance's power to give direction to the FSC should be strictly limited in the law.

\section{Given the stability risks, the FSC is appropriately strengthening the prudential} regime for securities dealers. The FSC has introduced a minimum capital adequacy ratio of 10 percent, limits on margin borrowing, and margin requirements for repos transacted with non-financial corporations and retail investors. Initially set at 1 and 3 percent for repos where the underlying security is, respectively, GoJ paper and other approved assets, the margin requirements were increased to 3 and 9 percent in September 2005 and are slated to rise to 5 and 15 percent in April 2006. The FSC has also put a cap on the growth of new retail repo business, limiting aggregate balances to the lower of either repo balances held on July 31, 2004 or 50 percent of a dealer's total assets and FUM.

\section{The margin requirements should be enhanced and strictly enforced, along with} other refinements to the prudential framework. The authorities recognize that the proposed margin required for repos in GoJ paper, the predominant product, of 5 percent is small relative to the potential price volatility of the underlying assets. They are thus contemplating a further increase in the margin requirement to 10 percent or to the use of a more sophisticated framework that differentiates the margins on repos according to factors

\footnotetext{
${ }^{9}$ Discussions with audit firms indicated that weaknesses in quarterly accounts of securities firms often result in the restatement of annual audited accounts, undermining the risk ratings of firms and off-site supervision.
} 
such as duration, liquidity and interest sensitivity gaps. ${ }^{10}$ While accepting the need for a phasing in to avoid disrupting the market, the FSAP mission urged the authorities to implement at least a 10 percent margin requirement before end-2006 and carefully screen those dealers who would be allowed to use the more sophisticated framework. Other refinements that should be made to the capital regime, some of which are recognized by the FSC, include: (i) refining capital adequacy to include a liquid capital requirement; (ii) introducing tiered initial capital requirements for different types of business that dealers engage in; (iii) introducing and monitoring restrictions on large exposures; and (iv) stipulating a deadline for transferring client money into segregated accounts. Moving to a more risk-sensitive prudential regime would obviate the need for a cap on repo business, which is a distortionary way to regulate the industry, although the FSC would need in the context of its supervisory visits to ascertain that dealers are applying appropriate margins.

37. There is a need to unify and rationalize fragmented regulations and tax regimes governing pooled investment vehicles. Tax and legal frameworks currently impede the establishment of mutual funds. But once these have been addressed, the FSC will need to intensify its oversight of mutual funds, with particular attention to asset valuation issues, requirements for pricing, and redemption of units.

\section{Encouraging the development of private pensions}

\section{Early parliamentary approval for the FSC to begin regulating private pensions}

is needed. The 2004 Pensions Act filled a void by establishing a detailed legal framework for private schemes. But until it receives formal parliamentary approval to be the regulator, the FSC cannot even begin registering existing pension funds. The subjection of all new pension regulations to affirmative parliamentary resolution should also be reviewed as it could reduce administrative flexibility to adjust to rapidly changing, technically complex circumstances.

39. The regulations should encourage the development of sound private pensions consistent with the structure of the economy. In a dynamic economy, particularly in the services sector, workers might change jobs many times during their lifetimes. The authorities have thus rightly made elimination of restrictions on the portability of pensions part of their reform plans. Since portability is seamless with employer-independent funds, their disadvantageous tax treatment should be eliminated, as called for in the government's White Paper on pensions, as soon as possible. In providing an enabling environment for employerindependent funds, regulatory and tax systems should avoid any bias in favor of defined-benefit schemes, which are more expensive to administer than defined-contribution schemes.

40. The detailed regulations should reflect the different risks of defined-benefit and defined contribution schemes. The risks and complexity of defined-benefit schemes mean

\footnotetext{
${ }^{10}$ Absent information on the fair value of securities, the authorities plan to allow firms to compute margins with reference to a "dirty price" only if they maintain the initial margin and are able to mark the underlying asset to market.
} 
they should be subject to strict solvency requirements. ${ }^{11}$ For defined-contribution schemes, the emphasis should be on disclosure and market discipline. In this context, the nature and low frequency of the reporting requirements imposed by the Registration, Licensing and Reporting Regulations issued by the FSC and the obligation for secrecy imposed by the Pensions Act would seem appropriate - although perhaps too costly_for established superannuation funds. But independent pension funds are not essentially different from mutual funds or other publicly-offered collective investment vehicles; to impose effective market discipline investors need to know accurately and frequently the value and composition of their portfolios.

\section{Cross-Sectoral Issues}

\section{A. Conglomerate Supervision}

\section{Although the supervisory and regulatory framework has been substantially} strengthened in recent years, important gaps remain. Where a group does not include a DTI, there are no legal provisions to enforce a reorganization, such as through a financial holding group. Legislative changes are needed to empower the FSC to obtain from related companies the information it requires to assess a group's consolidated financial position and formulate and enforce group prudential regulations. Nor does the BoJ have full legal powers to formulate and enforce prudential regulations for consolidated supervision, including capital adequacy, large exposure limits, and fit-and-proper requirements for the group. The BoJ and FSC lack powers to require consolidated (quarterly) prudential reports at the group level for effective off-site monitoring.

\section{Equally important, modalities for inter-agency cooperation need further} enhancing. The FRC's potential for information sharing and evaluating financial stability and contagion risks has yet to be fully exploited. Cross-border cooperation and information sharing has been enhanced via the BoJ's bilateral Memorandum of Understanding (MOU) with the Cayman Islands and a multilateral MOU with eight neighboring countries, and supervisors' participation in various regional groups of regulators. But until common regional approaches and standards are established, cross-border conglomerates will remain hard to supervise.

\section{The BoJ, FSC, and FRC all have important roles to play in strengthening the} supervision of conglomerates. The BoJ already has sufficient powers to carry out a degree of consolidated supervision of groups that include DTIs; its efforts should be intensified. Meanwhile, supervisory gaps can be addressed in the proposed Omnibus Bill, which should be completed, reviewed by FRC members, and presented to parliament at an early date. The FSC should begin working on changes to its legislative powers to enable it to conduct effective consolidated supervision and begin to better apply consolidated supervision principles in its work. The FRC should play an enhanced coordinating role. Given that

\footnotetext{
${ }^{11}$ The widespread problems in the UK pension industry in the early 2000s, and recent problems in retirement funds offered by US airline and automobile companies are illustrative.
} 
supervisory approaches differ between bank and nonbank entities, it should appoint a joint working group to develop a framework for prudential supervision of conglomerates and to draft supporting regulations. The FRC should also institute more formal protocols to enhance information sharing and working-level contact between agencies outside of crisis or intervention situations.

\section{Designating lead supervisors for conglomerates would facilitate ongoing} coordination and implementation of a more consolidated approach. The lead supervisor could be tasked with ensuring the necessary communication and joint work takes place to monitor financial stability and ensure that the conglomerate's activities meet prudential requirements on a consolidated and continuing basis. Lead supervisors in the context of intervening an institution are defined in the MOU that established the FRC as the supervisor exercising jurisdiction/oversight of the highest asset value within the group. This is consistent with generally agreed international practices, although other practical considerations could inform the choice. Responsibility for supervising individual entities within the group would continue to reside with the relevant agencies.

\section{Further down the road, a unified regulator might make more efficient use of} limited resources, and reduce regulatory arbitrage. The case for a unified agency would need to be weighed against risks of a lack of clarity of objectives and moral hazard (e.g., some market participants might assume that deposit protection covers all supervised entities), as well as the risk that concentrating power under one authority would lead to calls to limit the operational independence of the supra-regulator. The transition to a unified supervisor also entails risks that it opens up the need for parliamentary approval of new supervisory legislation and increases staff management problems in supervisory agencies.

\section{B. Crisis Management and Safety Nets}

46. Crisis management systems should be updated given the considerable changes in the financial and regulatory system. The priorities are to strengthen early warning systems and make the joint-agency intervention matrix (which, among other things, deals with resolution and exit issues for problem institutions) more comprehensive and operational. The Deposit Insurance Act should be modified to enable the insurer to participate more fully in resolution processes.

\section{The authorities have strengthened capabilities to diagnose potential stability} problems, but more can be done to increase cross-sectoral coordination. The BoJ has began to produce regular, internal financial stability reports on banks and the FSC carries out some stability analysis of the nonbank sector. Coordination of analysis across agencies would help to better understand quantitative links between institutions and across sectors, and to anticipate contagion risks. All major financial institutions should be required to undertake regular stress tests and report the results to their respective supervisory agencies.

48. The FRC is the logical body for coordinating work on crisis management. Crisis planning should evaluate how all systems and procedures might function in a crisis and whether legal or practical obstacles might impede their effectiveness. Simulations ("war 
games") of the most probable events should be designed and carried out as a coordinated exercise to identify weak spots.

49. Safety nets appear to be satisfactorily designed, although some modifications are needed. The Jamaica Deposit Insurance Corporation (JDIC) provides coverage for individual deposits up to $\mathrm{J} \$ 300,000$, which is equivalent to 1.8 times per capita GDP. However, JDIC assets only amount to 1.4 percent of insured deposits and should be built up more rapidly than planned to provide adequate coverage. The investment of these assets should also be diversified to include high quality, liquid foreign government obligations; currently, they are 100 percent invested in government securities. A recent JDIC internal simulation exercise revealed some practical and legal uncertainties that would prevent it from meeting its target of making payouts within 3 months; the gaps should be closed. The JDIC would also benefit from greater legal certainty to choose potentially less-costly work-out options in resolution cases. On other safety nets, the BoJ's overnight overdrafts and lender of last resort facility for deposit-taking institutions and authorized primary dealers appear satisfactorily designed.

\section{Anti-Money Laundering}

50. Jamaica has put in place most of the basic elements for a comprehensive AML/CFT framework, but important shortcomings remain. ${ }^{12}$ The legislation does not yet cover all categories of serious offences and does not apply to designated nonfinancial businesses and professions (DNFBPs). While Jamaica has signed the UN counter-terrorism financing convention, implementing legislation and mechanisms can be strengthened including stronger provisional measures for dealing with terrorism-related assets. There is also a need to review the legislation and arrangements for non-profit organizations to mitigate the risk of abuse for CFT purposes. The Financial Intelligence Unit (FIU) should be placed on a more solid statutory footing, and its mandate and operations strengthened to support its efforts to join the Egmont Group of FIUs.

\section{The Jamaica AML/CFT regulatory and institutional regime for the financial} sector is reasonably comprehensive and incorporates most FATF customer due diligence requirements. However, the regulatory framework can be strengthened in some areas such as explicitly prohibiting the use of anonymous and fictitious name accounts, and requiring due diligence on certain beneficial owners of accounts and transactions. The BoJ has implemented a program of onsite inspections of DTIs and money remitters that includes verification of compliance with the AML/CFT requirements. And the FSC has recently developed AML/CFT examination procedures for non-deposit taking institutions, although it has yet to be fully implemented. A key challenge for both regulatory agencies will be to conduct AML/CFT supervision of financial groups on a consolidated basis. Absent legislation, there is no AML/CFT supervision of DNFBPs.

\footnotetext{
${ }^{12}$ Jamaica's compliance with the Financial Action Task Force (FATF) 40+9 principles was assessed by the FATF-style regional body (CFATF) in April 2005. A Report on the Observance of Standards and Codes (ROSC) will be issued shortly.
} 
52. The authorities are working to close gaps in the AML/CFT framework. They are preparing comprehensive revisions to the Proceeds of Crime Act to modernize the AML/CFT framework, including strengthening the FIU and expanding the regime to cover DNFBPs. Efforts to strengthen consolidated supervision of financial conglomerates will also improve the capacity of the BoJ and the FSC to supervise AML/CFT risk on a group-wide basis. Enhanced supervisory capacity and training will be needed.

53. Jamaica has implemented reasonably adequate mechanisms for domestic and international cooperation on AML/CFT. A National Anti-Money Laundering Committee, which includes the principal AML/CFT stakeholders in Jamaica, has been established to coordinate activities at the national level. The BoJ's MOUs with a number of regional supervisors cover AML/CFT issues. However, supervisory cooperation could be strengthened in specific areas such as the development of multi-sector AML/CFT supervisory guidelines and procedures for consolidated supervision. On the international front, there are also cooperation mechanisms including for mutual legal and law enforcement assistance. Certain limitations still exist, however, such as the ability of the FIU to share information directly with foreign counterparts. This could be facilitated by membership in the Egmont Group.

\section{KEY DEVELOPMENT AND INFRASTRUCTURE ISSUES}

\section{A. Access to Credit}

54. A key challenge is to foster banks' contribution to economic development through expanding credit on reasonable terms. Macroeconomic forces are a major obstacle: public debt reduction is essential to crowd-in more lending and reduce lending rates. Credit unions are providing an additional avenue for credit. However, measures to improve credit supply conditions would help, including:

- $\quad$ Passing draft legislation to enable establishment of a credit reference agency.

- $\quad$ Modernizing insolvency procedures and creditor rights systems. The insolvency laws are out of date and serve the needs of neither debtors nor creditors. The system has no efficient means by which debtors can rearrange their affairs and preserve a potentially profitable entity. There are no provisions for insolvency practitioners to be regulated, licensed or bonded.

- Improving the efficiency of enforcement of secured rights. Financial institutions rely heavily on real estate as collateral. Most traded real estate is registered and procedures for taking and registering security are relatively efficient. But foreclosure, receivership and litigation are time-consuming and costly, and auctions attract few realistic bids. The procedure for securing chattels under the Bills of Sale Act is outdated and relatively inefficient, although it is popular security with credit unions.

- $\quad$ Providing more resources to the courts to reduce the considerable delays in litigation. The court system seems free from interference and corruption but is substantially 
under-resourced. The Commercial Court has been under-used since it opened in 2002 and the new Civil Procedure Rules have not reduced waiting lists.

\section{B. Payment and Settlement Systems}

55. Payment and settlement systems have major shortcomings. Jamaica has two systemically important systems, the BoJ-operated Customer Inquiry and Funds Transfer System (CIFTS) and the privately-owned electronic automated clearing house (ACH), as well as an electronic system for retail banking services-ATM machines and electronic funds transfers. However, an assessment of the two major systems against international core principles identifies important weaknesses:

- $\quad$ The legal framework leaves open questions about the finality of payments, the validation of netting arrangements and the protection of the payment system in case of bankruptcy of participants. This, plus an explicit settlement guarantee, exposes the BoJ to significant settlement risk.

- $\quad$ Absence of fully secure backup systems and business continuity plans, a lack of prompt settlement (three days for $\mathrm{ACH}$ ), and narrow operating hours further increase risks and add to inefficiencies.

- The BoJ's oversight function of the payments system is not effectively established.

56. The authorities recognize the shortcomings and are encouraged to expedite their reform agenda. This includes strengthening the legal framework, launching a modern automated system based on real time gross settlement (RTGS) and removing all large value items from the check clearinghouse. To help establish effective payment system oversight, a formal cooperative body (the National Payment System Council), led by the BoJ, was established in August 2005.

57. Efforts to integrate the government securities infrastructure with the large value system are needed to guarantee the smooth functioning of the payments system and create a more active market for government paper. Current arrangements need to be enhanced to allow for securities market transactions to be settled on a safe and efficient basis through true delivery versus payment. The BoJ should carefully evaluate the impact of all decisions related to securities markets, in particular the design of the much-needed CSD for fixed-income securities, on the overall safety of the national payments system.

\section{Monetary Policy Implementation and Related Market Infrastructure}

58. Monetary policy is implemented in an effective and generally transparent manner. Although multiple objectives are prescribed in the law, in practice open communication by the BoJ clarifies key objectives and contributes to policy accountability. The BoJ enjoys a high degree of independence, which is expected to be further strengthened shortly by passage of a revision to the BoJ Act to explicitly limit the scope of the Minister of Finance to override monetary policy decisions. Monetary policy is oriented around a base money target and the BoJ has well-developed operational structures and instruments to 
monitor, forecast, and manage liquidity effectively. In general, BoJ policies provide an enabling environment for the development of the money market: BoJ overdraft rates are set at punitive rates and banks cannot mobilize part of their reserve requirements to finance their clearance requirements.

59. Central bank losses should be addressed. Annual losses have been running at more than 1 percent of GDP as the BoJ has been sterilizing sizable foreign exchange rate inflows through open market operations (OMO). Concerns that such losses could give rise to internal conflicts in the BoJ's implementation of monetary policy are attenuated by the requirement under the BoJ Act for the government to cover the central bank's operating losses at the end of each fiscal year. However, the losses effectively create liquidity by transferring more cash to external entities than the central bank receives. It could therefore become self-defeating to push up central bank rates to squeeze liquidity when there is a large stock of OMO instruments (currently about 29 percent of GDP) to roll over.

60. The BoJ's financial position limits the phasing out of reserve requirements due to the cost of mopping up the liquidity that would be released. After the financial crisis, reserve requirements were as high as 25 percent, but have been progressively reduced to 9 percent. In the mini-crisis of 2003, special reserve requirements of 5 percent on local currency deposits were introduced, although they were reduced to 1 percent in the first half of 2005. Unlike reserve requirements on local currency deposits, those on foreign currency deposits are remunerated at the policy rate of the central bank of issue. This creates some incentive for dollarization and should be reviewed.

61. Introducing the CSD and electronic trading platforms would help develop the deep private repo market. An electronic trading platform would make for more transparent market arrangements, enhance price discovery and reduce the wide interest rate range. The introduction of the CSD would reduce settlement risks and contribute to more liquidity in the money market and over-the-counter treasury security market.

62. The exchange rate is largely market determined, although market infrastructure needs upgrading and surrender requirements appear anachronistic and should be reviewed. ${ }^{13}$ BoJ efforts to seek an appropriate electronic trading platform to replace the overthe-counter foreign exchange market are encouraged. An electronic system would foster development of a local forward foreign exchange market, which currently does not exist.

\section{Ensuring Continued Effective Public Debt Management}

63. The government has a publicly-available debt management strategy. Stated objectives are to lower borrowing costs and maintain a prudent and diversified debt structure, use market mechanisms for domestic debt issuance, promote a liquid and efficient market for

\footnotetext{
${ }^{13}$ Under the surrender requirement, authorized foreign exchange dealers and cambios are required to sell 5 percent of their gross purchase of foreign exchange to the BoJ. In addition, the government sells to the BoJ the proceeds of its foreign borrowing and bauxite operators sell foreign exchange directly to the BoJ.
} 
government securities, and increase the transparency and predictability of debt issuance. To this end, it aims to increase the share of the fixed-rate component of domestic debt to 60 percent and extend the maturity profile of debt. There is also a standing policy to limit external borrowing to the extent of the needs for gross external amortization.

\section{Progress toward the objectives has been achieved, but adjustments to the strategy and operational framework should be considered:}

- $\quad$ Targets for lengthening the debt maturity profile and reducing exposure to foreign exchange risk would provide benchmarks to objectively measure progress by.

- $\quad$ The MOF should conduct systematic and regular analysis of the vulnerabilities of the debt profile.

- $\quad$ Current heavy reliance on private placements for issuing fixed-rate instruments should be minimized. They provide too much discretion to the MOF, are not fully transparent, and may not always be consistent with minimizing borrowing costs.

- $\quad$ The MOF could further increase transparency by disclosing information on the results of debt issuance.

65. More active efforts to establish benchmark issues for GoJ securities and a market-determined yield curve would improve the liquidity for instruments, encourage participation of a wider cross-section of investors, and reduce the refinancing risks of the debt stock. Greater competition could cut debt costs especially where an auction process is used to price and allocate securities. Issuing benchmark securities would enhance efforts to establish a yield curve for government securities, which has been met with several challenges including low liquidity in GoJ securities and trading predominantly in maturities up to two years. Introduction of automatic trading systems might be considered. This has helped to enhance transparency, price discovery, and market depth in some countries, for example, South Africa and Mauritius. 


\section{Stress Testing OF THE BANKING SySTEM}

\section{Stress tests were conducted on all deposit-taking institutions (DTIs) using} end-2004 data to identify potential vulnerabilities. The tests were designed and carried out in conjunction with BoJ staff. The BoJ has considerably enhanced its capacity to perform quantitative risk analysis and introduced, among other tools, a stress testing exercise as part of its regular vulnerabilities assessment. The analysis assessed DTIs' resilience to both credit and market (interest rate, exchange rate, equity prices) risks. The calibration of shocks took into account historical variability in relevant variables. However, macroeconomic scenarios proved hard to design because the trend recovery in bank balance sheets since the 1996/97 financial crisis obscures the link between fluctuations in macroeconomic variables and bank profitability and asset quality. Absence of consolidated data for financial conglomerates also limited analysis of potential contagion effects across the financial system. Preliminary bank profit and balance sheet data for 2005 suggest that the broad conclusions of the stress tests would not alter with more recent data.

\section{Credit risk}

67. DTIs seem relatively resilient to credit risks, although some financial institutions may be vulnerable to problems in particular economic sectors. Given the adequacy of the capital base, DTIs in aggregate could withstand a three-to-fourfold increase in NPLs before capital adequacy fell below required levels (Figure 6). Such an increase in NPLs would push gross NPLs to about 14 percent of gross loans, levels last seen in the aftermath of the financial crisis. However, if the shock is evenly distributed across DTIs, the capital base of three banks and three building societies fall would fall below the required minimum. The main sectoral vulnerability appears to be personal lending (which includes mortgage lending). However, again the shock would need to be relatively large: if 20 percent of personal loans became nonperforming, one commercial bank and some building societies become undercapitalized; and if personal sector NPLs rose to 23 percent, the aggregate capital of building societies falls below the 10 percent minimum requirement.

68. It is hard to evaluate the likelihood of a major decline in credit quality or what might trigger it. Annual fluctuations in NPLs since 1998 have been comparatively small and dominated by a trend decline (Figure 5 of main text). This has occurred against a background of relatively stable, but low GDP growth, but periodic large swings in interest and exchange rates. Absence of data on house prices precludes analysis of risks of overvaluation and hence correction. Data were not available on the quality spectrum of loans between those that are, for example, classified as watch, sub-standard, or in loss. 


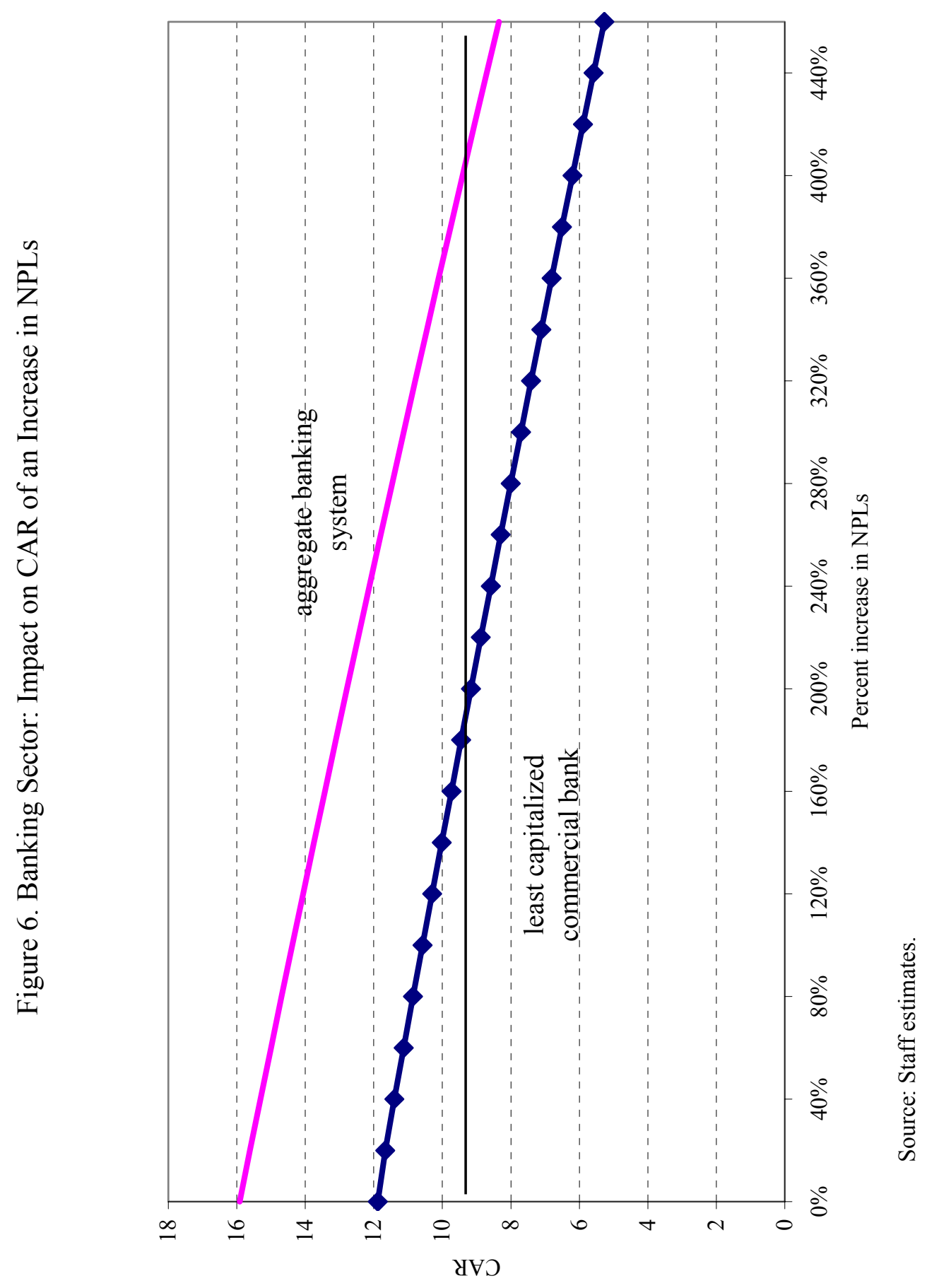




\section{Market and liquidity risks}

69. The banking system could absorb relatively sharp interest rate hikes, but a few small institutions are potentially vulnerable. The stress tests used a combination of repricing gap and duration mismatch models to estimate the cash flow and balance sheet impact of interest rate increases. ${ }^{14}$ These tests show that most commercial banks could withstand interest rate hikes of 1,000 basis points or more across the entire spectrum of the local currency yield curve for 12 months. However, two small banks with long durations and negative repricing gaps seem vulnerable to such large shocks (Table 8). For two building societies and one merchant bank, capital bases could be impaired assuming more modest interest rate shocks of 500 basis points.

70. In practice, the assumptions underlining the tests would be violated by the ability of DTIs to respond to higher interest rates by raising lending rates. Their latitude to do this is unclear, and would depend on several factors, including how permanent and large the initiating interest rate shock was. The mission was told that building societies tend to pass through rate hikes to customers fairly quickly. However, an inspection of average lending rates for all banks over the last 6-7 years suggests that overall lending rates have tended to be rather sticky with respect to movements in policy interest rates. To the extent that higher interest rates are passed on to loan customers, market risk would be converted into credit risk-i.e., the risk that borrowers might be pushed toward default. However, given that NPLs have not varied substantially in recent years despite relatively wide movements in policy interest rates (including an upward spike of more than 20 percentage points in 2003), such credit risks appear to have been small. Moreover, deposit rates have also been sticky in the face of policy rate hikes, perhaps reflecting the perceived safe-haven benefits of banks, and suggesting that rises in banks' cost of funds would be circumscribed. On balance, therefore, the judgment is that DTIs would be better placed to withstand an interest rate shock than the stress tests suggest.

71. In aggregate, exchange rate risks appear minimal, although one merchant bank could be vulnerable. The direct effects of devaluation appear negligible as net open positions are either positive or, if negative, relatively small. ${ }^{15}$ Instead, the main risks are indirect because of a high proportion of foreign currency lending (over one third) and potential mismatches between the currency denomination of borrowers' income and expenses. To capture indirect effects, the stress tests assumed a graduated spectrum of default

\footnotetext{
${ }^{14}$ All DTIs, except for one commercial bank and two building societies, have positive cumulative repricing gaps.

15 There are no prudential requirements against open positions, but the capital adequacy regulations require capital coverage of 10 percent of the higher of the aggregate of all net long and all net short foreign currency positions.
} 
and recovery rates on foreign currency loans for different levels of depreciation. ${ }^{16}$ However, only one merchant bank appears to carry any notable risk (Figure 7). Nonetheless, a sharp depreciation could be potentially damaging if followed by large interest rate hikes.

72. Banks could also withstand sizable equity price declines. Given the relatively small share of investment in equities in total assets, on aggregate, DTIs would remain adequately capitalized even with a 50 percent decline in the stock market index —although one building society's capital could fall below the minimum requirement with a 40 percent drop in the value of its stock holdings. ${ }^{17}$ Moreover, since capital gains on equities are not included in regulatory capital, most DTIs would likely be able to rely on a buffer of capital from the steep rise in the Jamaican stock market in recent years to offset potential market downturns.

73. High liquidity ratios and moderate loan-to-deposit ratios suggest that potential liquidity risk is low. The loan-to-deposit ratio of the aggregate banking system has been steadily increasing from 31 percent in 2000 to about 50 percent in 2004 . However, this is still low by international standards. Most liquid funds are channeled to government financing.

\section{Systemic risks}

74. Interbank contagion risks appear small, but the presence of financial conglomerates may be a potential source of contagion across different parts of the financial system. The highly limited interbank lending in Jamaica suggests that contagion risk among deposit-taking institutions is fairly low. However, the strong presence of financial conglomerates, which control about 80 percent of the financial system's assets, could foster contagion across sectors. To illustrate potential contagion effects, the impact of a failure of an insurance company that is 100 percent owned by a commercial bank was estimated. Results show that the parent company's capital ratio could fall below the minimum requirement if it assumes more than 10 percent of the subsidiary's liabilities, and falls to zero if it assumes 60 percent. However, this does not lead to further failures of other DTIs in the system.

75. All financial institutions are highly exposed to domestic sovereign credit risk, making this an overarching vulnerability. In a catastrophic scenario whereby the government suspended payment or restructured its debt, the financial system could therefore amplify the macroeconomic consequences as all financial segments would be simultaneously affected and could lead to insolvency for some of the highly exposed. However, there is no history of the government ever failing to honor its commitments. And, relative to the position before the financial crisis, financial sector supervision has been strengthened substantially and the banking system is better capitalized.

\footnotetext{
${ }^{16}$ It is not clear how to calibrate the default rates. However, doubling the steepness of the assumed default profile does not change the results qualitatively.

${ }^{17}$ Legal restrictions on banks' holdings of equities also limit their exposure to the stock market.
} 
Table 8. Summary of Stress Testing Results, as of End-December 2004 (In percentage points, unless otherwise indicated)

\begin{tabular}{|c|c|c|c|c|}
\hline & $\begin{array}{c}\text { Total banking } \\
\text { system }\end{array}$ & $\begin{array}{c}\text { Commercial } \\
\text { banks }\end{array}$ & $\begin{array}{c}\text { Merchant } \\
\text { banks }\end{array}$ & $\begin{array}{l}\text { Building } \\
\text { Societies } \\
\end{array}$ \\
\hline \multicolumn{5}{|c|}{ (Change in CAR as a result of the shocks in percentage points) ${ }^{1 /}$} \\
\hline \multicolumn{5}{|l|}{ Impact of an increase in interest rates } \\
\hline+500 basis points & $-0.2(3)$ & $0.1(0)$ & $0.0(1)$ & $-1.9(2)$ \\
\hline+1000 basis points & $-1.7(4)$ & $-1.3(1)$ & $0.1(1)$ & $-6.4(2)$ \\
\hline+1500 basis points & $-4.7(7)$ & $-3.0(2)$ & $0.1(2)$ & $-26.3(3)$ \\
\hline \multicolumn{5}{|l|}{ Impact of a depreciation in exchange rate of } \\
\hline $10 \%$ & $0.1(1)$ & $0.1(0)$ & $-0.4(1)$ & $0.4(0)$ \\
\hline $30 \%$ & $0.3(1)$ & $0.3(0)$ & $-1.1(1)$ & $1.2(0)$ \\
\hline $\begin{array}{l}50 \% \\
\text { together with defaults in foreign currency loans }{ }^{2 /}\end{array}$ & $0.5(1)$ & $0.5(0)$ & $-1.8(1)$ & $1.9(0)$ \\
\hline $10 \%$ & $-0.2(1)$ & $-0.3(0)$ & $-0.6(1)$ & $0.4(0)$ \\
\hline $30 \%$ & $-0.6(1)$ & $-0.8(0)$ & $-1.7(1)$ & $1.1(0)$ \\
\hline $50 \%$ & $-1.2(1)$ & $-1.5(0)$ & $-3.0(1)$ & $1.7(0)$ \\
\hline \multicolumn{5}{|l|}{ Impact of credit deterioration } \\
\hline \multicolumn{5}{|l|}{ Rise in NPLs by 360 percent with 100 percent } \\
\hline provisioning & $-5.8(7)$ & $-5.2(3)$ & $-1.5(1)$ & $-14.0(3)$ \\
\hline 20 percent of loans to a major sector in each institu & es NPL ${ }^{3 /}$ & $-1.4(2)$ & $-0.4(1)$ & $-7.0(3)$ \\
\hline 100 percent risk weights on government papers & $-4.8(2)$ & $-5.3(1)$ & $-2.5(1)$ & $-4.7(0)$ \\
\hline \multicolumn{5}{|l|}{ Impact of equity market decline } \\
\hline 50 percent falls in the major equity index & $-2.0(2)$ & $-1.3(0)$ & $-2.2(1)$ & $-6.0(1)$ \\
\hline \multicolumn{5}{|c|}{ (Change in liquidity ratio as a result of the shocks in percentage points) } \\
\hline \multicolumn{5}{|l|}{ Impact of liquidity risk } \\
\hline Removal of government papers from liquid assets & -5.7 & -6.2 & -7.9 & -4.2 \\
\hline \multicolumn{5}{|l|}{ Memorandum items: } \\
\hline Risk weighted assets (in percent of the total) & 100 & 72.6 & 13.4 & 14.0 \\
\hline Capital adequacy ratio & 15.1 & 15.9 & 9.9 & 16.3 \\
\hline Buffer capital/risk weighted assets & 7.8 & 5.0 & 6.7 & 23.5 \\
\hline
\end{tabular}

Source: Staff estimates.

1/ Numbers in parentheses represent number of institutions falling below minimum capital adequacy requirement. $2 /$ Assuming that depreciation increases the default rate ( 2 percent- 10 percent) and reduces the recovery rate (20 percent- 2 percent). 3/ With 50 percent provisioning. 


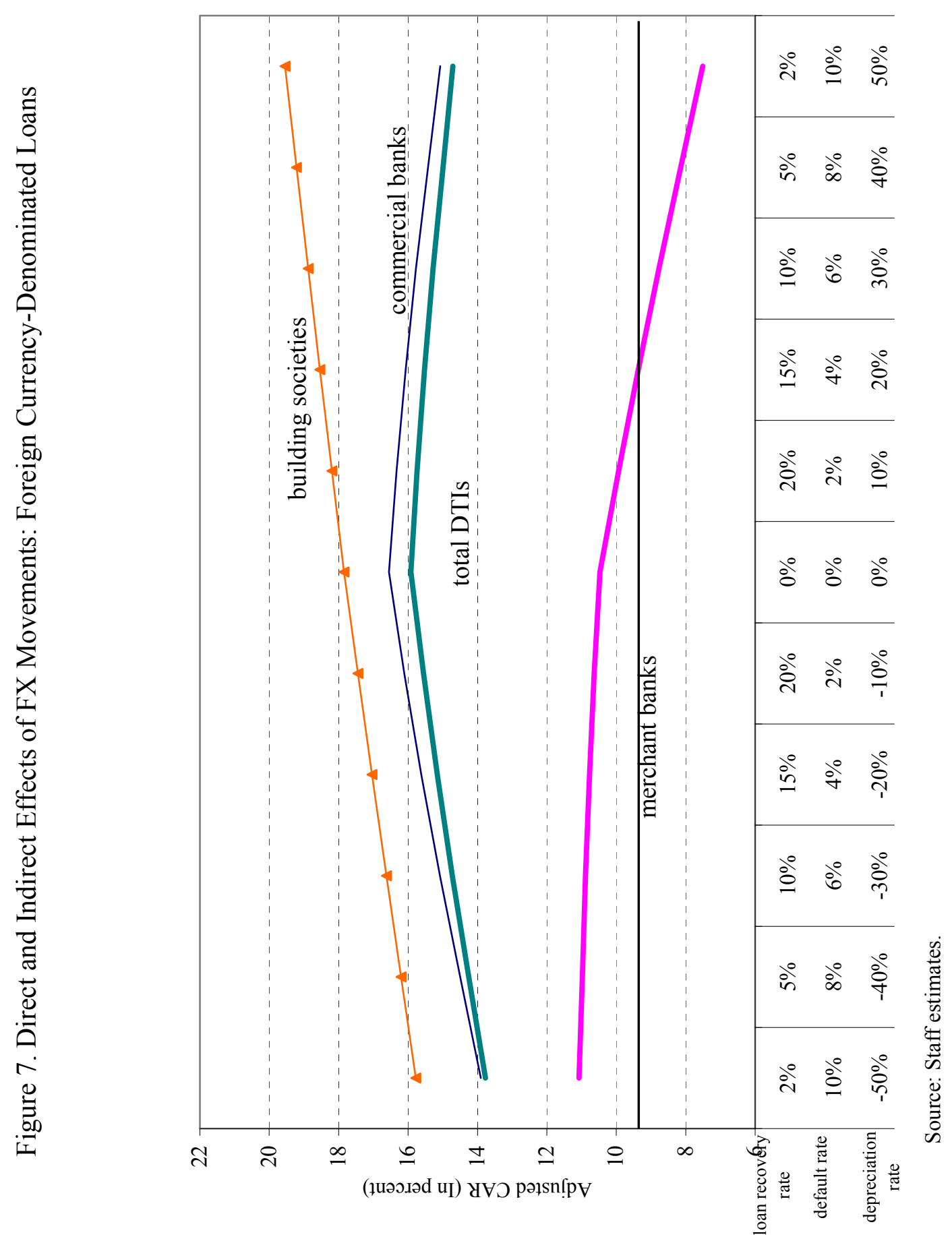




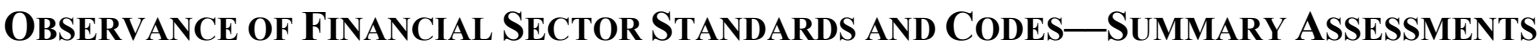

\section{Basel Core Principles for EfFective Banking SuPERVision ANd Transparency of BANKING SUPERVISION}

\section{General}

76. This assessment of BoJ's compliance with the Basel Committee's Core Principles for Effective Banking Supervision (BCP) was conducted on May 16-26, 2005 as part of the joint IMF/World Bank Financial Sector Assessment Program (FSAP). It was conducted by José De Luna Martinez, Robert Liu and Gyeongsoo Bae of the World Bank. The three assessors formerly worked for the banking authorities in Mexico, Canada, and South Korea. The assessment was based on a review of relevant laws, regulations, standards of best practices and other guidelines related to the financial sector. It also included discussions with BoJ and other relevant authorities and stakeholders including the Ministry of Finance and Planning, the Financial Services Commission, the Jamaica Deposit Insurance Corporation, commercial banks, state-owned banks, bankers association, accounting and auditing profession.

77. The BCP team received full cooperation from the Jamaican authorities and the private sector. This included receiving relevant information necessary for the assessment. The BCP team would like to express its gratitude to the BoJ, other government ministries and agencies as well as the private sector institutions for their assistance. In preparing this report, the assessors used the assessment methodology prescribed in the Core Principles Methodology published by the Basel Committee on Banking Supervision.

\section{Institutional and macroprudential setting, market structure-overview}

78. The BoJ has legal responsibility for bank supervision in Jamaica. The BoJ's parameters for operations, mandate, objectives and responsibilities for bank supervision are specified in the Bank of Jamaica Act (BoJA) of 2002, Banking Act (BA), Financial Institutions Act (FIA), and Building Societies Act (BSA). This set of laws empowers the BoJ to supervise all deposit taking institutions (DTIs), comprising commercial banks, merchant banks, building societies, as well as and credit unions. The BoJ is also responsible for supervising money transfer companies, cambios and exchange bureaus. Within the BoJ, the Financial Institutions Supervisory Division (FISD) is the unit responsible for the supervision of all above institutions.

79. Jamaica has a large financial system. Total financial sector assets are almost twice the level of the country's GDP. The financial system consists of 15 deposit-taking institutions and numerous nonbank financial institutions. In the banking system, commercial banks are the dominant entities with assets equivalent to more than 60 percent of GDP at end-2004. Nonbank financial institutions consist of credit unions, financial houses and trust companies, securities dealers, insurance companies, cambios (foreign exchange traders) and pension funds. But while the financial system is deep, much of it is oriented toward financing the government. The banking sector generally appears to be sound and profitable. The sector is 
adequately capitalized by international standards, with an aggregate capital adequacy ratio of about over 16 percent as of end-2004.

80. As a result of the financial crisis of 1996-97, the banking system has undergone major changes. The authorities prevented meltdown during the crisis, but at great fiscal cost-some 35-40 percent of GDP. After the crisis, the number of commercial banks, insurance companies, and building societies fell sharply and foreign ownership increased. There are currently six commercial banks and, by assets, foreign ownership amounts to some 97 percent. The crisis also prompted a revamping of supervision.

\section{General preconditions for effective banking supervision}

81. Most pre-conditions for effective banking supervision exist in Jamaica, including a stable (albeit vulnerable) macroeconomic environment, a generally well-developed public infrastructure, market discipline, procedures for the resolution of insolvent banks and a safety net for banks. However, there is still a need to address specific areas that may affect the quality of banking supervision, including excessive government debt, lack of a credit bureau, an ineffective insolvency regime, legal impediments that prevent the deposit insurance from acting before a bank reaches insolvency, and weaknesses in the payments system.

\section{Main findings}

82. During the past five years, Jamaica has made impressive progress in updating its regulatory and supervisory framework to bring it further into line with best practice. However, there are still important impediments to fully effective supervision that need to be addressed in the areas of operational independence for supervisors and consolidated and conglomerate supervision.

- Objectives, Autonomy, Powers, and Resources (CP 1). The objectives of the BoJ in relation to bank supervision are clearly defined in relevant laws. BoJ management and staff have good qualifications, are knowledgeable and receive training on a regular basis. Also, they are protected from liability when performing their supervisory responsibilities in good faith, by an explicit provision in the BoJA. However, the BoJ does not have operational independence and powers to issue legally binding regulations. BoJ does not have the power to grant and withdraw licenses or set legally binding prudential rules and, in many cases, the power to take prudential decisions rests with the Minister of Finance, who usually acts on the recommendation of the BoJ. One issue that requires attention is the shortage of staff in the FISD.

- Licensing and Structure (CPs 2-5). The Banking Act provides a general definition of "banking business" and the licensing criteria of banks. Also, relevant laws define "controlling interest" and notification and approval requirements for changes in ownership and management. However, pre-notification requirements are not embedded in laws or regulations. Apart from these weaknesses, Jamaica generally 
complies with these Principles. Jamaica prohibits individuals with a record of wrong doing in financial institutions from becoming board members. This is a sound practice that needs to be maintained without exceptions.

- $\quad$ Prudential Regulations and Requirements (CPs 6-15). Jamaican banks have to maintain a minimum primary capital ratio of 6 percent and a minimum risk-weighted capital ratio of 10 percent. The risk-weighted ratio is based on the model of the Basel Capital Accord. In some respects, the definitions used are stricter than those found in the Basel Accord. There are comprehensive rules for credit policies and the evaluation of loans and loan-loss provisions. The definition of large exposure (CP 9) should be provided in laws or regulations and consolidated reporting should be implemented. The law should be amended to include provisions that will ensure lending to related parties is done at arm's length. The supervisory guidelines on country risk (CP 11) have been issued recently, even though, at present, such exposures are limited to Jamaican banks. For market risks (CP 12) there exist supervisory guidelines for risk management and reporting, but no capital charges, other than for open foreign exchange positions, are imposed. For other banking risks (CP 13) supervisory guidelines have been implemented and are generally in line with international standards. These will need to be updated and enhanced to address increasingly complex activities of banks. Jamaica complies with the Principle on internal control systems (CP 14), the BoJ having issued guidelines mandating a number of control mechanisms within banks. As in other countries, the challenge is to focus the control functions more on policies, procedures, and systems, while not neglecting the traditional monitoring of transactions and operations. Existing money laundering guidelines (which are issued by the $\mathrm{BoJ}$ ) to address (CP 15) are adequate but some improvements are under way.

- Methods of Ongoing Supervision (CPs16-20). The framework for on-site and off-site supervision, which is based on a CAMELS+R approach, is adequate. The procedures for on-site examinations are laid down in a manual. The most critical and overarching deficiency deals with weaknesses in the consolidated supervision regime. Since the last BCP assessment in 2001, BoJ has made enormous progress in laying the ground to carry out supervision of financial groups on a consolidated basis. BoJ now has authority to require the re-organization of financial groups so that it can get information from all entities in a group. Moreover, the obstacles to share information and cooperate with other domestic or foreign supervisory agencies have been removed and now BoJ can fully cooperate with other supervisory bodies. Despite this remarkable progress, BoJ still needs to develop the tools to supervise institutions on a consolidated basis, including basic prudential norms - consolidated capital, extragroup exposure limits, etc.- - and train its staff on consolidated supervision.

- Information Requirement (CP 21). Jamaica largely complies with this Principle. Reporting generally complies with international accounting standards (IAS). Effective 2002, IFRS must be used for reporting. Audited financial statements must be published within three months after fiscal year-end. External audits have to be 
conducted according to International Auditing Practices. The audits cover a broad range of issues, including loan quality, loan loss identification and provisioning, asset valuation, trading activities and internal controls. Also, external auditors have a statutory duty to inform the supervisory agency within a stated timeframe if they detect any matters of significant importance to the bank concerned. To be fully compliant with this principle, it is important, that BoJ is given the legal power to revoke a bank's auditor.

- $\quad$ Formal Powers of Supervisors (CP 22). The range of remedial actions is adequate. Also, the power to impose temporary management in a problem bank, without the consent of the Minister, represents a significant improvement from the previous regime. However, the issue of granting and revoking a license remains in the hands of the Minister. This is still an unresolved issue that will best be solved by granting that power to the BoJ.

- Cross-Border Banking (CPs 23-25). These Principles relate to cross-border banking such as cooperation between home and host country supervisors and the exchange of information, consolidated supervision on a global basis, and equal treatment of foreign establishments. MOUs have been signed with neighboring countries in the Caribbean. The same standards are applicable to local and foreign-owned banks operating in Jamaica.

Table 9. Recommended Action Plan to Improve Compliance of the Basel Core Principles

\begin{tabular}{|c|c|}
\hline Reference Principle & Recommended Action \\
\hline CP 1.1 & $\begin{array}{l}\text { It is recommended that the proposed Omnibus Bill be passed in order to harmonize existing } \\
\text { legislation for commercial banks, merchant banks and building societies. It is also } \\
\text { recommended to strengthen the legal foundations of the Financial Regulatory Council. }\end{array}$ \\
\hline CP 1.2 & $\begin{array}{l}\text { The BCP team believes that BoJ needs to be completely independent from the Ministry of } \\
\text { Finance. To ensure this, appointment of senior bank supervisors should be a responsibility of } \\
\text { Parliament. It is also recommended that the powers to grant or revoke licenses to deposit } \\
\text { taking institutions be transferred from the Ministry of Finance to the BoJ, as in the case of } \\
\text { FSC, which has the powers to grant or revoke licenses for the institutions it supervises. }\end{array}$ \\
\hline CP 1.3 & Legislation to empower BoJ to set legally binding regulations should be passed. \\
\hline CP 1.6 & There is a need to strengthen the legal basis of the FRC. \\
\hline CP 2 & $\begin{array}{l}\text { To mitigate supervisory arbitrage between different types of banks, and create "a level playing } \\
\text { field," the Omnibus Bill should be passed. }\end{array}$ \\
\hline CP 3 & $\begin{array}{l}\text { The amendments proposed by the authorities to strengthen the licensing criteria for new banks } \\
\text { should be passed. }\end{array}$ \\
\hline CP 4 & $\begin{array}{l}\text { The current practice of requiring pre-notification for any ownership changes of } 5 \text { percent } \\
\text { should be embedded in law. }\end{array}$ \\
\hline CP 5 & The need for prior notice should be codified in existing legislation. \\
\hline CP 7 & Establish a credit bureau. \\
\hline CP 9 & $\begin{array}{l}\text { Amend the legal framework to define the term "large exposure," which should include all } \\
\text { claims, on-balance sheet and off-balance sheet. }\end{array}$ \\
\hline CP 12 & $\begin{array}{l}\text { Although regulations on market risk are already in place, the supervisors need now to improve } \\
\text { their capacity to monitor the complex market activities of banks. }\end{array}$ \\
\hline
\end{tabular}




\begin{tabular}{|c|c|}
\hline Reference Principle & Recommended Action \\
\hline CP 16 & $\begin{array}{l}\text { Some delays were observed in the presentation of official reports with findings of on-site } \\
\text { examinations to bank management. It is important that the presentation of official findings be } \\
\text { done more rapidly. BoJ also needs to address the shortage of staff, resulting from the } \\
\text { departure of staff in the supervision areas in the past years. Additional staff should be } \\
\text { recruited to allow BoJ to fulfill its objectives on time. }\end{array}$ \\
\hline CP 17 & $\begin{array}{l}\text { After each examination, the examiners should meet with the Board of Directors to discuss the } \\
\text { examination results. This is currently being done on an exceptional basis. It should be a norm. } \\
\text { If the Board is not available they should at least meet with the Chairman of the Audit } \\
\text { Committee. }\end{array}$ \\
\hline CP 18 & There is a need to improve risk management monitoring and analysis. \\
\hline СР 19 & $\begin{array}{l}\text { Legislation needs to be amended to empower BoJ to replace a bank's external auditor } \\
\text { whenever deemed necessary. }\end{array}$ \\
\hline CP 20 & $\begin{array}{l}\text { Despite the remarkable progress made by authorities to strengthen the consolidated } \\
\text { supervision regime in } 2002 \text {, much remains to be done in order for consolidated supervision } \\
\text { framework to be fully operational. This includes: } \\
\text { - } \quad \text { Enactment of the Omnibus Bill } \\
\text { - The completion of the restructuring plan by FIs } \\
\text { - } \quad \text { Establishment of prudential regulations on a group-wide basis } \\
\text { - Drafting of reporting forms on a consolidated basis }\end{array}$ \\
\hline CP 21 & $\begin{array}{l}\text { The BoJ should consider establishing a committee comprising members from } \mathrm{BoJ} \text { and the } \\
\text { audit profession to exchange information and continue improving the overall accounting and } \\
\text { auditing framework. }\end{array}$ \\
\hline CP 22 & $\begin{array}{l}\text { The issue of granting and revoking a license remains in the hands of the Minister. This is still } \\
\text { an unresolved issue that will best be solved by granting that power to the BoJ }\end{array}$ \\
\hline
\end{tabular}

\section{Authorities' response}

83. In general, the authorities viewed the assessment as a strict interpretation of the Principles, although felt that it did not give due consideration to the environment in which they are being implemented. Most weaknesses in the legal framework that have been identified in this assessment will be solved once the Omnibus Law is passed.

84. The BoJ expressed disappointment with the findings for CP 3 and CP 5. On CP 3, the BoJ argued that the law is specific on the bases for license approval. The current regulations, detail a comprehensive set of documents that must be submitted to the Supervisor, including business plans and projections, comprehensive questionnaire to facilitate fit and proper assessment, audited financials to evaluate financial soundness etc. In addition, Section 29 D of the financial statutes outlines acceptable group structures for DTIs, while Section 13 sets investment limits. These regulations (which are intended to be uniform for all DTIs now supervised), will be revised and updated to ensure comprehensiveness and relevance in the review of the legal framework currently underway, in the form of the proposed Omnibus bill. On CP 5, BoJ felt that there was sufficient legal guidance in terms of appropriate investments for banking groups as well as prescribed limits on investments and stressed that the criteria could not be too prescriptive - it was not the BoJ's role as supervisor to get into the details of commercial decisions. 
85. In addition, the BoJ asked that the assessment give due credit to the enormous efforts that have been done to establish the framework for consolidated/conglomerate supervision in the context of the Jamaican environment with its conglomerate group structures, a situation which is not adequately addressed by the Core Principles, which deals with consolidated supervision of banking groups only. In this regard, the BoJ would welcome recommendations from the FSAP team as to how best to address this complex supervisory issue as this would go a long way in advancing work in formulating a regulatory regime for this area.

\title{
Summary Assessment Report on the CPSS Core Principles for Systemically IMPORTANT PAYMENT SYSTEMS
}

\author{
Systemically Important Payment Systems
}

\section{General}

86. The assessment of systemically important payment systems in Jamaica with the Committee for Payment and Settlement Systems (CPSS) Core Principles (CPs) for Systemically Important Payment Systems (CPSIPS) was conducted in the context of a Financial Sector Assessment Program (FSAP) joint IMF-World Bank mission that visited Jamaica from May 11-13, 2005. Two systems were assessed, the central bank operated Customer Inquiry and Funds Transfer System (CIFTS) and the automated check clearinghouse $(\mathrm{ACH})$. Securities settlement systems were not assessed in detail. The assessment was performed by Massimo Cirasino, (Senior Financial Sector Specialist, World Bank). The main counterparty agency for the assessment was the BoJ, whose full cooperation was greatly appreciated.

\section{Payment systems infrastructure—overview}

87. Cash and checks are the major means of making payments in Jamaica. However, in recent years efforts have been made to establish and improve electronic funds transfer systems. An important achievement was BoJ's setting up of CIFTS in 1993. Participants can enter instructions to the system throughout the day on accounts held at the central bank. Payment instructions entered into the system are deemed final as the BoJ guarantees all outgoing funds transfer instructions. CIFTS lacks several of the key features of a modern, safe and efficient large value payment system and exposes the BoJ to important risks.

88. In October 2002, a privately owned automated clearinghouse (ACH) replaced the manual clearing system operated by the BoJ, allowing the electronic clearing and settlement of negotiable instruments among the seven clearing banks. Since checks are used to execute some large value payments in Jamaica, the $\mathrm{ACH}$ presents important financial risks. The newly formed Jamaica Clearing Bankers Association (JCBA), which is comprised of the clearing banks (BoJ and the six commercial banks), is responsible for the administration of the $\mathrm{ACH}$ and the enforcement of its Rules and By-laws. Customers receive cleared funds on a check deposit within $\mathrm{T}+3$. Electronic products such as direct debits and credit transfers will be processed through the $\mathrm{ACH}$ when the second phase is implemented. New clearing 
processes to further speed up clearing and settlement, such as check truncation and digital imaging using checks as the source of information to create an electronic payment at point of sale or point of deposit and electronic payment products will be implemented in later phases.

89. In addition, the Jamaican financial services industry has created a service platform for noncash retail banking services, JETS Limited. The system utilizes a shared Electronic Transaction Switching Network that allows withdrawals at cash dispensers and electronic funds transfer (EFT) services, facilitates payments by providing debit Point of Sale (POS) services, and effects settlement between members. Debit cards used for withdrawing cash or making payments in an EFT/POS environment are fully interoperable among JETS' members. Interbank claims arising from such services are settled through JETS own clearinghouse on member banks settlement accounts. Settlement takes place on a net basis on the business day following transaction date.

90. The securities market in Jamaica is dominated by Government of Jamaica (GoJ) debt. The GoJ issues Treasury Bills, Local Registered Stock, Debentures, US dollar Indexed Bonds, and US dollar Bonds. The BoJ, as agent of the government, has established an electronic front-end system, e-Gate, for the issue of government securities in the primary market. This allows the 14 Primary Dealers and 6 commercial banks to have direct access to primary issues of GoJ securities. The trading of government securities takes place over-the-counter (OTC). Securities dealers may use CIFTS or checks to settle securities trades, while the Ministry of Finance (MOF) as registrar administers the transfer of legal title.

91. The sale of equity securities is conducted on the Jamaica Stock Exchange (JSE). During the past several years, the JSE has modernized its operations. The first step was the establishment of the Jamaica Central Securities Depository (JCSD), a wholly owned subsidiary of the JSE, in January 1999. The JCSD as well as broker dealers operate accounts at the BoJ and transfer funds through CIFTS for the settlement of equity trades. The JSE has also implemented an electronic trading system called SUNRISE. Since the trading system is linked to or coupled with the JCSD's system, trades are executed through book entry transfers of ownership of the securities. In order to trade, a security is blocked in the account of the seller before the security is traded and the transfer of title is effected when payment is received. In 2004, the monthly value of stocks traded was J\$2.41 billion.

92. The JCSD is proposing to expand its services for the custody, trading and settlement of fixed income securities. The long-term objective is to have all new issues of GoJ and BoJ securities issued directly into the depository. The JCSD will link securities transfers to funds transfers in a way that achieves delivery versus payment (DvP) without the need for the movement of the physical securities, thereby reducing the cost associated with settlement and custody and the risk of destruction or theft of certificates and checks.

93. In February 2005 the BoJ embarked on a process of comprehensive reform of the local payment and settlement systems to enhance the safety and efficiency of these systems focusing on: (1) The implementation of a real time gross settlement (RTGS) system that will replace the current CIFTS system. A central securities depository is to be linked to the RTGS 
system in order to achieve the effective and efficient integration of securities trades with settlement on a DvP basis; (2) The establishment of a National Payments Council comprised of representatives from all the major stakeholders including financial regulators, financial institutions, the Ministry of Finance, and with the BoJ playing a leadership and facilitating role; (3) The development of legislation and the implementation of an appropriate legal framework for payment systems; (4) The development of the payment system oversight function in the central bank.

\section{Main findings}

94. The CIFTS and ACH are considered of systemic importance in Jamaica. Both do not observe many of the Core Principles. Therefore, several aspects of the systems need to be redesigned including proactive measures to reduce the systemic importance of the check clearinghouse. Additional elements include: an assessment of the legal risk; the implementation of effective risk management measures to reduce the settlement risks incurred currently by the central bank; an extension of operating hours; an improvement of the overall efficiency of the system; an effective interconnection with other systems (in particular with the government securities settlement system); a better management of operational risks with the implementation of very tight measures for physical and operational security; business continuity and resilience (including a secondary site located in a distant location); routines for channeling government payments early in the operating day; and more effective governance arrangements.

95. The BoJ does not observe fully many of the responsibilities in applying the CPSIPS. It therefore needs to establish its oversight function over the payments system as a whole and have the ability to exercise its oversight function effectively. In order to enhance cooperation in the payments system, a formal cooperative body, led by the BoJ, (National Payment System Council) was created in August 2005.

96. Important efforts to integrate the government securities infrastructure with the large value system should be put in place soon, to guarantee both the smooth functioning of the payments system and the creation of a more active market for government papers. Also, current arrangements need to be enhanced to allow for securities market transactions to be settled on a safe and efficient basis (i.e. through true delivery versus payment, DvP). The BoJ should carefully evaluate the impact of all decisions related to securities markets (in particular the design of the new CSD for fixed-income securities) on the overall safety of the national payments system.

97. It is recognized that the BoJ's reform program will address many of the weaknesses in the payments system. The authorities are encouraged to make early implementation of the program a priority. 
Table 10. Recommended Actions to Improve Observance of CPSS Core Principles and Central Bank Responsibilities in Applying the CPs

\begin{tabular}{|c|c|}
\hline Reference principle & Recommended action \\
\hline $\begin{array}{l}\text { Legal foundation } \\
\text { CPI-The system should have a } \\
\text { well-founded legal basis under all relevant } \\
\text { jurisdictions. }\end{array}$ & $\begin{array}{l}\text { Pending legal issues are being addressed as a priority by the BoJ. } \\
\text { A comprehensive legal framework is being established as part of } \\
\text { the overall payment systems reforms. This includes the } \\
\text { development of a Payment Systems Act and provisions in Law for } \\
\text { the oversight role of the central bank. A complete set of rules and } \\
\text { procedures will be developed to govern the Payment System. } \\
\text { Also, the medium-term plan for payment system reforms includes } \\
\text { the replacement of CIFTS with a LVTS. This system is intended } \\
\text { to have the legal underpinnings as prescribed by this principle. } \\
\text { The highest priority should be given to the legal reform project. }\end{array}$ \\
\hline $\begin{array}{l}\text { Understanding and management of risks } \\
C P S I I-I I I\end{array}$ & $\begin{array}{l}\text { Both CIFTS and ACH participants are aware that the BoJ } \\
\text { implicitly guarantees settlement at the end of the day. However, } \\
\text { the BoJ should define rules and operating procedures that include } \\
\text { issues covering the management of settlement risk. } \\
\text { Credit risk is minimized to participants through the implicit } \\
\text { guarantee of the central bank. However, this arrangement should } \\
\text { be modified as a matter of urgency to reduce BoJ risk exposures. } \\
\text { The BoJ's plan to introduce a RTGS system would eliminate } \\
\text { credit risk for the central bank and other systems participants and } \\
\text { should be pursued as a matter of urgency. } \\
\text { Specifically, for CIFTS: (1) the BoJ should also provide } \\
\text { information to participants on their operating account balances in } \\
\text { real time. (2) The redesign of the system through the launch of the } \\
\text { RTGS should contemplate the provision of management tools to } \\
\text { handle liquidity risks. They include: queuing mechanisms } \\
\text { eventually with procedures of optimization mechanisms; efficient } \\
\text { operating hours and interconnections among the systems (in } \\
\text { particular with the securities settlement systems); routines for } \\
\text { channeling government payments early in the operating day; the } \\
\text { provision of intraday liquidity through intraday repos with } \\
\text { application of haircuts. In absence of these mechanisms, liquidity } \\
\text { risk could become relevant. } \\
\text { For ACH, risk management procedures (such as guarantee funds } \\
\text { and/or participant agreements such as loss-sharing agreements), } \\
\text { should be introduced and monitored over time depending on the } \\
\text { degree of systemic importance of the clearinghouse. }\end{array}$ \\
\hline$\frac{\text { Settlement }}{C P s I V-V I}$ & $\begin{array}{l}\text { The central bank should eliminate the delay in posting the CIFTS } \\
\text { settlement operations on participants' accounts in order to ensure } \\
\text { that "settlement finality" also occurs in the accounting system } \\
\text { procedures. } \\
\text { For ACH, some items are settled on } \mathrm{T}+1 \text {. However, it is not } \\
\text { recommended to reduce the settlement cycle to } \mathrm{T}+0 \text {, but rather to }\end{array}$ \\
\hline
\end{tabular}




\begin{tabular}{|c|c|}
\hline Reference principle & Recommended action \\
\hline & $\begin{array}{l}\text { ensure that the check clearinghouse loses its status as SIPS. } \\
\text { Payments likely to generate systemic risk (in particular large value } \\
\text { payments) should be settled in other types of system (see CP III). } \\
\text { For both CIFTS and ACH the legal issue on finality (in case of } \\
\text { bankruptcy by one or more participants) should be dealt with in } \\
\text { the context of legal reform. }\end{array}$ \\
\hline $\begin{array}{l}\text { Security and operational reliability, and } \\
\text { contingency arrangements }\end{array}$ & \multirow[b]{2}{*}{$\begin{array}{l}\text { In light of the planned launch of the RTGS system, the BoJ should } \\
\text { implement the back-up site, develop a comprehensive Business } \\
\text { Continuity Plan for the large value system and conduct tests on an } \\
\text { ongoing basis. It should also implement an adequate overall } \\
\text { security policy for the new RTGS and define clear and well } \\
\text { documented objectives and procedures, standards for the } \\
\text { protection of the data communication infrastructure that conform } \\
\text { to commercially reasonable standards and a proactive approach to } \\
\text { identify sources of operational risks. } \\
\text { For the check clearinghouse, the JCBA should implement the } \\
\text { back-up site, develop a comprehensive Business Continuity Plan } \\
\text { for the large value system and conduct tests on an ongoing basis, } \\
\text { under the supervision of the BoJ. }\end{array}$} \\
\hline$C P V I I$ & \\
\hline Efficiency and practicality of the system & \multirow[b]{2}{*}{$\begin{array}{l}\text { The BoJ should discuss with CIFTS participants any changes } \\
\text { required to further enhance the safety and efficiency of the system. } \\
\text { Pricing policies should be carefully formulated and used to } \\
\text { rearrange payment transactions in a more efficient and secure way } \\
\text { among the available and future systems and instruments, in } \\
\text { particular by removing large value checks from the check } \\
\text { clearinghouse. } \\
\text { The implementation of the RTGS system and the launch of phase } \\
2 \text { of the ACH project will create the conditions for a further } \\
\text { enhancement of the efficiency of the check clearinghouse. } \\
\text { Commercial banks and the BoJ are encouraged to move forward } \\
\text { with their plans to reduce the use of checks in Jamaica. }\end{array}$} \\
\hline$C P$ VIII & \\
\hline Criteria for participation & \multirow{2}{*}{$\begin{array}{l}\text { The BoJ should provide for transparent participation criteria by } \\
\text { setting eligibility standards in order to ensure the financial and } \\
\text { technical reliability of the system. }\end{array}$} \\
\hline$C P I X$ & \\
\hline Governance of the payment system & \multirow{2}{*}{$\begin{array}{l}\text { The BoJ is aware of the CIFTS' shortfalls and is seeking } \\
\text { compliance with the Core Principles through the launch of an } \\
\text { RTGS system. In order to pursue efficiency and reliability of the } \\
\text { system, the BoJ should establish effective and accountable } \\
\text { organizational and governance arrangements, consistent with the } \\
\text { Core Principles. Formal users' group should be created as a matter } \\
\text { of urgency to address all system's needs also from the }\end{array}$} \\
\hline$C P X$ & \\
\hline
\end{tabular}




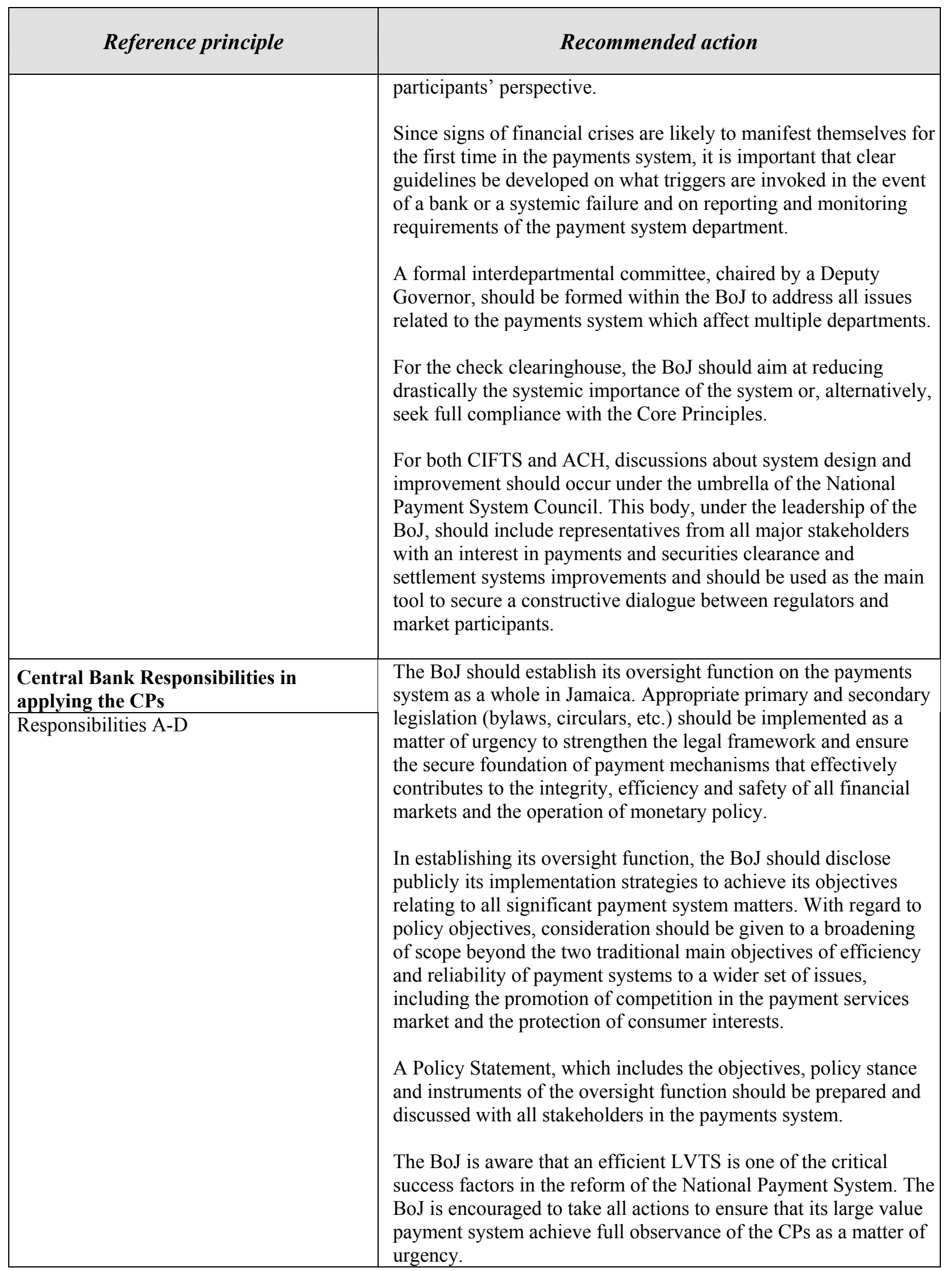




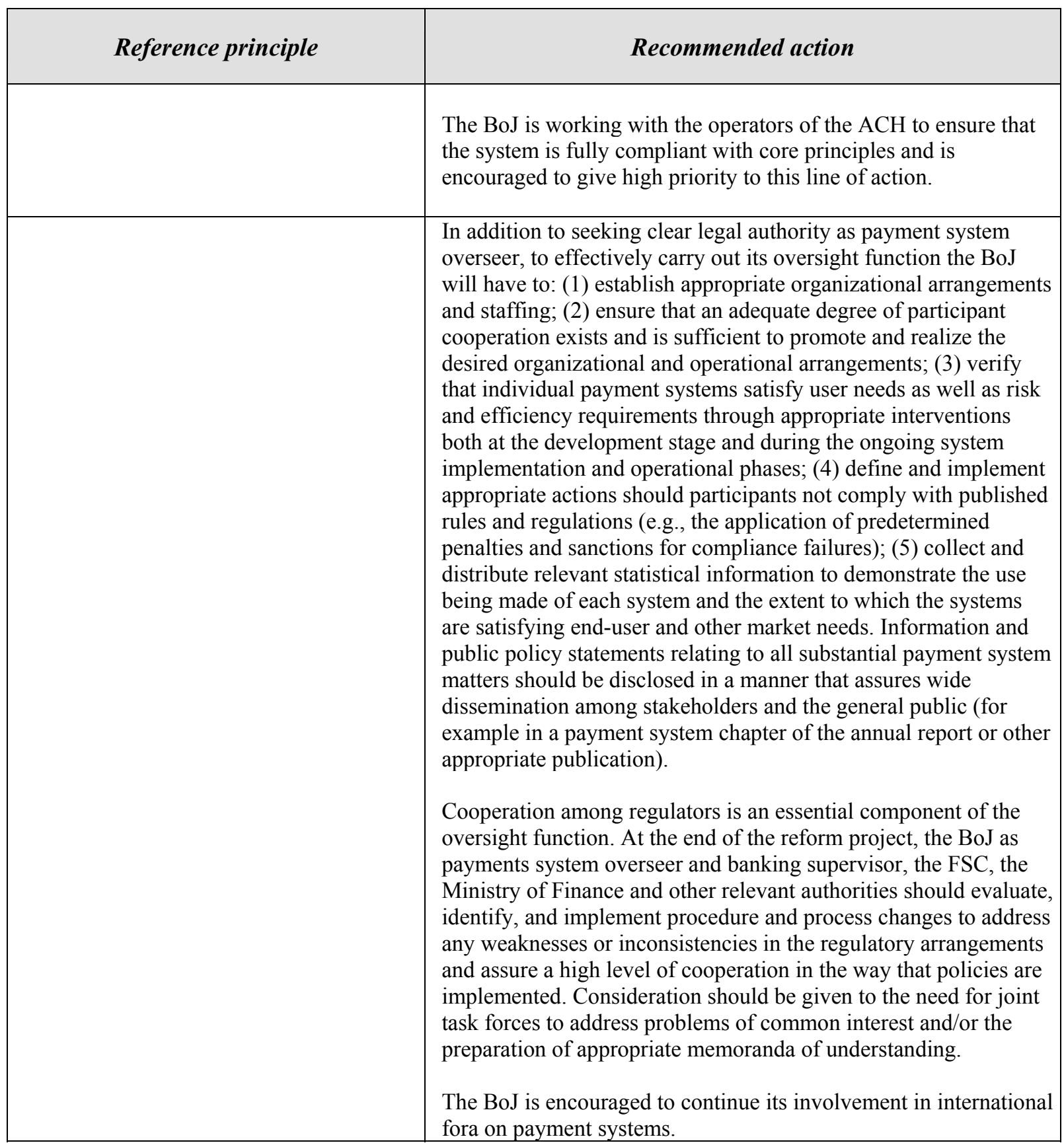

\section{Authorities' response}

98. The deficiencies have already been identified and the recommendations are being pursued by the central bank. The BoJ considers it critical to embark on a process of comprehensive reform of the payment and settlement systems. This will encompass (a) the legal and regulatory framework, (b) the modernization and integration of the payment 
systems, including the CSD, and (c) the establishment of the oversight function for payments and securities settlement systems.

\section{IMF'S TRANSPARENCY CODES}

\section{A. Transparency of Monetary Policy}

\section{General}

99. This Assessment examines the observance by the BoJ of the IMF Code of Good Practices on Transparency of Monetary and Financial Policies (MFP Transparency Code) for monetary policy. ${ }^{18}$ The assessment is based on (i) a review of relevant laws, regulations and policies; (ii) analysis of documentation provided on the BoJ website and a variety of BoJ publications; and (iii) discussion with staff of the BoJ and selected commercial banks. The assessment took into consideration the principles stipulated in the MFP Transparency Code and implementation issues mentioned in supporting documents to the MFP Transparency Code. The Jamaican authorities cooperated fully with the assessment and provided all of the necessary information and documentation requested by the mission.

\section{Summary of Main Findings}

100. The BoJ has legal responsibility for the conduct of monetary policy. The parameters for the operations of the BoJ, its mandate, objectives and responsibilities for the conduct of monetary policy are specified in the BoJA. Overall, while the BoJ has achieved a high degree of transparency in the actual conduct of monetary policy, the provisions of the law as specified in the BoJA have lagged behind the practices. The authorities have nevertheless presented to Parliament draft legislation which will align the legal provisions with the actual practices.

\section{Clarity of roles, responsibilities and objectives of the central bank for monetary policy}

101. The objectives and institutional framework of monetary policy are stipulated in the BoJA, but the Act in its current formulation does not legislate for full transparency and accountability in the conduct of monetary policy. The legislation clearly confers authority on the BoJ to utilize monetary policy instruments, but the objectives of monetary policy as specified in the BoJA imply a simultaneous pursuit of multiple policy objectives. There is also no explicit requirement in the law for the BoJ to have a monetary policy statement that specifies the targets of the Bank and the policies by which it intends to achieve those objectives, nor is there a requirement to present a monetary policy program either to Parliament or to any other forum. The Minister's authority with respect to monetary policy is also not confined to exceptional circumstances.

\footnotetext{
${ }^{18}$ The Assessment was undertaken by Mr. Emilio Sarcedoti and Ms. Inutu Lukonga as part of the joint IMF/World Bank FSAP missions that took place May 9-20 and July 6-14, 2005.
} 
102. The authorities have presented to Parliament draft legislation which, inter alia, addresses these concerns. This draft legislation is to be supplemented by additional proposals that were approved by the BoJ's Board.

\section{Open Process for Formulating and Reporting Monetary Policy Decisions}

103. The process for monetary policy formulation, implementation and communication is consistent with the principles specified in the code. There is a well established internal Economic Policy Committee and an Operating Targets Committee that, respectively, meet weekly and daily to formulate and implement monetary policy. Information about the composition, structure and functions of monetary policy making body are disclosed on the website of the BoJ, although the minutes of the meetings are not disclosed.

104. The framework for monetary policy, its instruments and targets are discussed in numerous publications available on the web-site. These publications also discuss the procedures and practices governing monetary policy instruments and operations. The rules and procedures for the central bank's relationships and transactions with counterparties in its monetary operations and in the markets are also clearly stipulated in the Act.

105. The Governor holds regular meetings with the press and also appears before cabinet to explain the monetary policy stance and other economic developments. Changes in the setting of monetary policy instruments are communicated through press releases and interviews that provide direct interactions with the markets, in a timely manner. Progress in achieving monetary policy objectives are also discussed in the quarterly report on monetary policy, which is published on the web site.

\section{Public availability of information on monetary policy}

106. There is an extensive set of publications on the web-site that discuss developments in monetary policy. These include the monthly economic reviews, the Quarterly Monetary Policy Report (QMPR), annual reports, research papers and statistical publications. Jamaica also participates in the IMF's General Data Dissemination Systems (GDDS) and the authorities are currently reviewing plans to participate in the SDDS. The balance sheet of the BoJ is published on the web-site on a fortnightly basis.

\section{Accountability and assurances of integrity by the central bank}

107. Accountability for the conduct of monetary policy is ensured by virtue of the fact that the $\mathrm{BoJ}$ is required to transmit to the Minister of Finance, within three months of the close of the financial year, a report dealing with the operations of the BoJ. These reports are then presented to the House of Parliament by the Minister. Further, while the Act does not require the Governor of BoJ to appear before any public authority to report on the conduct of monetary policy and explain the policy objectives of its institutions, in practice the Governor of the BoJ does appear before Cabinet as needed to discuss the Bank's operations. 
108. The BoJ also has well established procedures that ensure the integrity of its operations. There is an internal audit department, external auditors who audit the accounts, and an Audit Sub-Committee of the Board, which is chaired by a nonexecutive director. Further, while the policy manual on the intra-net that discusses the Code of conduct are not publicly discussed, standards for the conduct of personal affairs are also governed by the corruption prevention act, which is in the public domain.

\section{Recommended Action Plan And the Authorities Response to the Assessment}

Table 11. Recommended Action Plan to Improve Observance of IMF's MFP Transparency Code Practices-Monetary Policy

\begin{tabular}{|c|c|}
\hline Reference Practice & Recommended Action \\
\hline $\begin{array}{l}\text { I. Clarity of Roles, } \\
\text { Responsibilities and Objectives of } \\
\text { Central Banks for Monetary } \\
\text { Policy }\end{array}$ & $\begin{array}{l}\text { Amend the law to clarify the objectives of monetary } \\
\text { policy. } \\
\text { Specify in the legislation the ultimate objectives of } \\
\text { monetary policy, as has been clarified in the range of BoJ } \\
\text { publications. } \\
\text { Legislate the requirement to prepare a monetary policy } \\
\text { statement that articulates the program objectives and } \\
\text { instruments to be used as well as require that that the } \\
\text { statement is presented before a public body. } \\
\text { Amend the law to ensure that the circumstances in which } \\
\text { the Minister overrides central bank policy decisions be } \\
\text { limited to exceptional circumstances and the exceptional } \\
\text { circumstances are clearly defined. }\end{array}$ \\
\hline
\end{tabular}

\section{Authorities' response}

109. The authorities generally agreed with the assessment. They drew attention to the fact that draft legislation that would facilitate compliance with the principles in the areas identified in the report was already before Parliament. 


\section{B. Transparency of Banking Supervision}

\section{General}

110. This assessment relates to the transparency practices of the BoJ as the authority responsible for banking supervision in Jamaica. The assessors were José de Luna Martinez, Robert Liu and Gyeongsoo of the World Bank. This work focused on the supervisory role of the BoJ, the activities of the BoJ, and BoJ's interaction with other financial sector authorities (MOF, JDIC and FSC).

111. The assessment was based on the MFP Transparency Code and its Supporting Document. The Jamaican authorities cooperated fully with the assessment and provided all the necessary information and clarifications.

\section{Main findings}

112. BoJ practices with respect to bank supervision are highly transparent. Practically all relevant laws, regulations, circulars, and standards of best practice for the banking industry are available in the BoJ's website. In addition, the BoJ disseminates its work on bank supervision through various means, including quarterly press briefings, website and other publications and articles, quarterly meetings with the industry umbrella association (the Bankers Association), quarterly meetings with supervised institutions, annual report and regularly scheduled meetings with supervised entities. The Governor holds regular meetings with the press and also appears before the cabinet to explain key decisions in terms of banking supervision and other issues. The Governor has the obligation to brief Parliamentarians whenever needed on any issue related to the BoJ's scope of responsibilities. The BoJ is obliged to disclose to the public details of its activities on a regular basis, including projects undertaken by the various Departments or Divisions in the Bank; contracts undertaken; the Bank's audited financial statements; and detailed commentaries on various financial sector issues - among other topics, the financial system, supervision of all deposittaking financial institutions, and financial legislation. Although there is room to continue improving transparency in banking supervision, Jamaica is in compliance with most internationally accepted practices covered by this report.

\section{Clarity of roles, responsibilities, and objectives of the banking supervisory agency}

113. The broad objectives of the BoJ are clearly defined in the BoJA as well as in other relevant banking sector laws, such as the Banking Act, the Financial Institutions Act, and the Building Societies Act. However, one problem that needs to be addressed is the lack of legal powers of the BoJ to issue legally binding regulations for the banking industry. In the absence of this type of power, the BoJ issues so-called Standards of Best Practices, which are not legally binding, but in practice are observed by all regulated entities. At this time, amendments to the law are being proposed to empower the BoJ to issue and amend all prudential regulations for the banking industry. 
114. In order to coordinate the activities of existing financial sector supervisory bodies in Jamaica, a Financial Regulatory Council (FRC), under the Chairmanship of the Governor of the BoJ, was formed in December 2001. The Council's mandate is to develop policies and strategies to facilitate greater coordination, reduce regulatory arbitrage and increase information sharing between the various supervisory agencies operating in the Jamaican financial sector. The FRC meets periodically, at least once per quarter, but in several instances on a monthly basis, to discuss any regulatory issues that exist in relation to BoJ and FSC regulated institutions.

\section{Open process for formulating and reporting of banking supervisory policies}

115. The BoJ consults with its supervised entities with regards to proposed changes to the structure of financial regulations. Submissions from the public (if any) are taken into account. However, there is no defined appropriate period for public consultations. This is done on an ad-hoc basis. Where changes are substantive/or have constitutional implications and will result in amendments to the law, the Minister of Finance and Planning may decide to submit the matter to a joint select committee of Parliament, which accepts submissions from the public for consideration.

\section{Public availability of information on banking supervision}

116. All laws applicable to financial institutions are available to the public on the BoJ's website. In addition, the BoJ website contains guidelines and standards of best practice that regulated institutions must observe. The BoJ also provides training as regards the finalized laws or guidelines to the affected industry. The BoJ publishes its Annual Report, which includes a comprehensive review of economic developments, including with respect to the performance of banking sector and regulatory changes and activities in terms of bank supervision. The BoJ also publishes the Statistical Digest and various reports comprising aggregated data on banking institutions. In addition, the BoJ has a fully staffed functional Public Relations Department that deals with public information issues and a Protocol and Media Relations Unit.

117. Whenever necessary, press conferences are organized to inform the public about important developments in the banking industry and the rationale for BoJ's actions in terms of bank regulation and supervision. Statements and press releases on banking sector issues are posted immediately in the BoJ's website. In addition, BoJ officials attend meetings at Parliament whenever they are required to explain the rationale for certain banking supervision decisions or actions.

\section{Accountability and assurances of integrity by the banking supervisory agency}

118. Section 44 of the BoJA calls for the submission of the audited financial statements to the Minister within three months of the close of the financial year and the publication of the financial statements immediately thereafter. The financial statements, which form part of the BoJ Annual Report, are published and made available to the public at the Government Printers in the Gazette. They are also posted on the BoJ's website. 
119. The BoJ's audited accounts are prepared by an independent auditor. Section 43 of the BoJA stipulates that the accounts of the BoJ shall be audited by auditors appointed annually by the Board with the approval of the Minister of Finance and Planning. Information on accounting policies and qualifications (if any) are an integral part of the report. In 2002 Jamaica adopted the International Financial Reporting Standard Board's IFRS and auditing standards. The BoJ complies with these international standards in the auditing and reporting of its financial statements.

120. The BoJA provides that the Governor and Deputy Governors may not engage in any other means of employment without the approval of the Minister of Finance and Planning and the Board of the BoJ. The BoJA also provides that the staff of the Banking Inspection Department should be subject to integrity standards. For instance staff in this Department are not permitted to invest in the shares of licensees regulated by the BoJ and are expressly prohibited from engaging in any other means of employment or office without the permission of the Minister.

121. The BoJ's Staff Rules and Orders and the Bank's Human Resources Manual also deal with these issues and provide for disciplinary action to be taken in the event of noncompliance with the BoJ's policies in this regard. In addition, the BoJ has a policy manual on the intra-net that discusses the Code of Conduct but these are not publicly disclosed. That notwithstanding, standards for the conduct of personal affairs are also governed by the Corruption (prevention) Act. This Act, which is in the public domain, requires staff whose emoluments exceeds a prescribed threshold to file an annual declaration of assets, liabilities, and income to a public commission for the prevention of corruption.

Table 12. Recommended Action Plan to Improve Observance of IMF's MFP Transparency Code Practices-Banking Supervision

\begin{tabular}{|l|l|}
\hline Reference Principle & \multicolumn{1}{c|}{ Recommended Action } \\
\hline 5.1 & $\begin{array}{l}\text { A problem that needs to be addressed is the lack of legal powers of BoJ to issue legally } \\
\text { binding regulations for the banking industry, which creates uncertainty about the legal } \\
\text { force of the standards of best practices issued by the BoJ. Although regulations are } \\
\text { formally issued by the MOF, there is a need to empower the BoJ to issue and amend all } \\
\text { prudential regulations for the bank industry, as it considers necessary. }\end{array}$ \\
\hline 5.3 & $\begin{array}{l}\text { The BoJ should establish formally its payment system oversight function. Appropriate } \\
\text { secondary legislation (bylaws, circulars, etc.) should be implemented to complete the legal } \\
\text { framework and ensure the secure foundation of payment mechanisms that effectively } \\
\text { contribute to the integrity, efficiency and safety of all financial markets and the operation } \\
\text { of monetary policy, especially in the area of securities settlement systems. In the context } \\
\text { of establishing the oversight function, the BoJ should disclose publicly its implementation } \\
\text { strategies to achieve its objectives relating to all significant payment system matters. }\end{array}$ \\
\hline 5.4 & $\begin{array}{l}\text { The FSC and the BoJ should, as a matter of urgency, define and disclose their relations to } \\
\text { effectively oversee SROs in the area of securities settlement. }\end{array}$ \\
\hline
\end{tabular}




\begin{tabular}{|l|l|}
\hline Reference Principle & \multicolumn{1}{c|}{ Recommended Action } \\
\hline & $\begin{array}{l}\text { The BoJ should require the League of Credit Unions of Jamaica to do much more in terms } \\
\text { of disclosing data and information to the general public through its website. }\end{array}$ \\
$\begin{array}{l}\text { With regard to the Clearing House, the BoJ and FSC should consider issuing formal } \\
\text { regulations for self regulatory organizations, especially in the area of securities settlement } \\
\text { systems. The regulation might consider extending the status of SRO to the new Central } \\
\text { Securities Depository (CSD), provided that the latter be regulated and capitalized } \\
\text { appropriately. }\end{array}$ \\
\hline 6.1 .4 & $\begin{array}{l}\text { The license fee structure for cambios should be publicly disclosed. } \\
\text { Consultations on proposed changes to financial regulations are made on an ad-hoc basis. It } \\
\text { is recommended that the obligation of BoJ to consult changes to regulation with affected } \\
\text { parties be reflected in the law. Situations in which consultation are not appropriate should } \\
\text { also be reflected in law. }\end{array}$ \\
\hline
\end{tabular}

\section{Authorities' response}

122. Generally, BoJ agreed with the report. It pointed out that it is currently working on a comprehensive regime for the Payment and Settlements Systems which includes upgrading/promulgating of relevant laws, that when completed will see compliance in this area. (See also report on payment systems.)

\section{Transparency of Financial Policies: JDIC}

\section{General}

123. This assessment relates to the transparency practices of the Jamaica Deposit Insurance Corporation (JDIC). The assessors were José de Luna Martinez, Robert Liu and Gyeongsoo Bae of the World Bank. The assessment was based on the MFP Transparency Code and its Supporting Document. The Jamaican authorities cooperated fully with the assessment and provided all the necessary information and clarifications.

\section{Main findings}

124. The JDIC practices with respect to financial policies are highly transparent. Practically all relevant laws, regulations and JDIC's broad objectives are available in the JDIC's website and the annual report. In addition, the JDIC disseminates its work on deposit insurance through various means, including media advertisements, the distribution of brochures and public fora for schools, community organizations and business and trade associations. In addition, the CEO and other senior officials frequently make themselves available for presentations and to answer questions from the public. The JDIC is obliged to disclose to the public details of its activities on a regular basis, including policy objectives and the audited financial statements and so on. Although there is room for continued improvement in transparency in deposit insurance system, Jamaica is in compliance with most internationally accepted practices covered by this report. 


\section{Clarity of roles, responsibilities, and objectives of the JDIC}

125. The broad objectives and institutional framework of the JDIC are clearly defined in the Deposit Insurance Act (DIA) and publicly disclosed. The JDIC's main objectives are to establish and manage a scheme for the insurance of deposits or parts of deposits against loss. The DIA also prescribes a limit for this insurance per depositor. In furtherance of these objectives, the DIA prescribes the establishment of a Deposit Insurance Fund from which depositors will be paid where a financial institution fails to do so by reason of intervention action taken by the Minister of Finance and Planning or the BoJ. The DIA prescribes that the policy and general administration of the JDIC and the management of the Deposit Insurance Fund is the purview of a seven member Board of Directors. Disclosure and explanation of the JDIC's broad objectives are made through the annual report and on the JDIC's website.

126. The relationship between the JDIC and the BoJ and the Ministry of Finance and Planning is specified in the DIA. Further, the JDIC is a member of the Financial Regulatory Council, which coordinates the activities of existing financial sector supervisory bodies in Jamaica.

\section{Open process for formulating and reporting of deposit insurance policies}

127. The activities of the JDIC are conducted in accordance with the DIA and the JDIC discloses information on its activities to the public on a consistent basis. The premium structure is detailed in the DIA and the premium rate is stipulated by regulations.

128. Arrangements for information sharing between the BoJ and the JDIC are documented in the DIA, however, no arrangements exist for sharing information between the JDIC and international agencies.

129. The JDIC's policy is to consult with the insured financial institutions before introducing regulations of a substantive technical nature. Collaboration would take place through the bankers' association and/or other association relating to a particular sector. Strictly, the external auditors of the relevant financial institutions should be involved.

\section{Public availability of information on deposit insurance}

130. Information on deposit insurance is communicated to the public on a consistent basis, by various means, including television and radio interviews, media advertisements, public fora, annual report, etc. However, the annual report is its primary publication for the disclosure of information on JDIC's activities. The aggregate premium received from insured financial institutions is disclosed to the public in the annual report and audited financial statement of the JDIC, as is the size of the Deposit Insurance Fund.

131. The CEO and other senior officials frequently make themselves available for presentations and to answer questions from the public. Also, JDIC officials can be required to appear before any relevant Committee of the Parliament of Jamaica such as the Public Accounts Committee and before the Cabinet. 


\section{Accountability and assurances of integrity by the JDIC}

132. The JDIC's audited financial statements are published annually in hard copy or on the website. The JDIC reports on the framework of its internal governance procedures, the composition of the Board, and the type and composition of the various JDIC Board Committees through its Annual Report. However, the JDIC has no permanent internal audit function which is outsourced because of the small operational size. Disclosure of these expenses and revenues is made through the Annual Report

133. The Board of Directors and employees are bound by the provisions of the Public Bodies Management and Accountability Act, which sets out the duties of the directors of public sector entities, the requirement for an Audit Committee, annual, quarterly and half-yearly reporting of the public sector entity to the responsible Minister, and prescribes limitations on the activities of public bodies regarding the purchasing of shares and borrowing.

134. The JDIC's Human Resource Manual also sets out that breaches of any ethical standards prescribed will subject the employee to disciplinary process. There is no explicit disclosure of these rules to the public as it can be accessed by the public under the Access to Information Act.

\section{Recommended Action Plan}

135. The JDIC is in full compliance with most practices contained in the IMF's MFP Transparency Code. There are, however, some areas in which more work is needed to improve the transparency of JDIC operations.

Table 13. Recommended Action Plan to Improve Observance of IMF's MFP Transparency Code Practices-JDIC

\begin{tabular}{|l|l|}
\hline \multicolumn{1}{|c|}{ Reference Practice } & \multicolumn{1}{c|}{ Recommended Action } \\
\hline VI. Open Process for Formulating and Reporting of Financial Policies \\
\hline $\begin{array}{l}\text { 6.1.5 Where applicable, formal } \\
\text { procedures for information } \\
\text { sharing and consultation between } \\
\text { financial agencies (including } \\
\text { central banks), domestic and } \\
\text { international should be publicly } \\
\text { disclosed. }\end{array}$ & $\begin{array}{l}\text { The JDIC may wish to consider establishing bilateral or multilateral } \\
\text { information sharing arrangements with foreign financial agencies in } \\
\text { addition to the membership with International Association of Deposit } \\
\text { Insurers (IADI) and disclosing them to the public. }\end{array}$ \\
\hline VIII. Accountability and Assurance of Integrity by Financial Agencies \\
\hline $\begin{array}{l}\text { 8.2.2 Internal governance } \\
\text { procedures necessary to ensure } \\
\text { the integrity of operations, } \\
\text { including internal audit } \\
\text { arrangements, should be publicly }\end{array}$ & $\begin{array}{l}\text { The JDIC should have permanent internal audit function in place within } \\
\text { its organization. }\end{array}$ \\
\hline
\end{tabular}




\begin{tabular}{|l|l|}
\hline \multicolumn{1}{|c|}{ Reference Practice } & \multicolumn{1}{|c|}{ Recommended Action } \\
\hline disclosed. & \\
\hline 8.4 Standards for the conduct of & $\begin{array}{l}\text { Unlimited disclosure of the Human Resource Manual can help assure the } \\
\text { personal financial affairs of } \\
\text { officials and staff of financial }\end{array}$ \\
agencies and rules to prevent & \\
exploitation of conflict of & \\
interest, including any general & \\
fiduciary obligation, should be & \\
publicly disclosed
\end{tabular}

\section{Authorities' response}

136. On practice 6.1.5, the JDIC noted that it has formal membership with the IADI and collaboration on international best practices takes place in this forum. This is disclosed in the Annual Report and where necessary in the press. It did not see the additional benefits of formal arrangements with international agencies and attendant disclosures as imperative within the current context of the JDIC mandate and its specific role in the domestic financial safety net.

137. On practice 8.2.2, the JDIC recognized and acknowledged the efficacy of having its internal audit function placed within its organizational structure in particular in the context of the sensitive nature of information with which it deals and the perceived and real risk of conflict of interest where the outsourced service provider services other clients. The JDIC noted that it has taken into account these issues in its present arrangements. Notwithstanding, JDIC's approach in using an outsourced service provider is seen as being a purely short-term measure which now allows some objective basis in helping to determine best practices for defining the parameters of the Corporation's internal control requirements. The near-term objective is to identify and establish a framework to coordinate and facilitate a corporate approach to managing corporate risk. This will encompass the internal audit function, within the context of the small organizational structure.

138. On practice 8.4, the JDIC noted that its interpretation of the Access to Information Act allows it to provide unlimited disclosure of its Human Resource Manual and other human resource policies that incorporate guidelines of the relevant government agencies. The Corporation's human resource policies, as incorporated into the contracts of employment of staff, also prohibit the exploitation of any conflict of interest affecting staff employed to the JDIC and recognize the compliance of corporate officers with the Corruption Prevention Act. Duties are also imposed upon corporate directors under the Public Bodies Management and Accountability Act which addresses, inter alia, the issue of the fiduciary duties and standard of care of directors, including the issue of conflict of interest. 